Danuta Adamiec*, Justyna Branna**, Dobromir Dziewulak***, Kamila Groszkowska****, Marcin Mróz ${ }^{* * * *}$, Łukasz Żołądek $^{* * * * * *}$

\title{
Analiza systemów nadzoru właścicielskiego nad przedsiębiorstwami państwowymi w wybranych państwach Unii Europejskiej (Czechy, Finlandia, Francja, Hiszpania, Litwa, Łotwa, Niemcy, Wielka Brytania, Włochy) ${ }^{1}$
}

W opracowaniu wskazano, że systemy nadzoru właścicielskiego są zróżnicowane - od scentralizowanego w Finlandii, Francji i Hiszpanii, przez system dualny we Włoszech, do systemu zdecentralizowanego w Wielkiej Brytanii, na Litwie i Łotwie. Szczegółowo opisano poszczególne modele, wskazując podmioty sprawujące nadzór nad omawianym typem przedsiębiorstw.

Słowa kluczowe: przedsiębiorstwo państwowe, nadzór, Unia Europejska, własność

Analysis of systems of ownership supervision over state-owned enterprises in selected countries of the European Union (Czech Republic, Finland, France, Spain, Lithuania, Latvia, Germany, United Kingdom, Italy): The study shows that corporate governance systems varies from centralized ones in Finland, France and Spain, a dual one in Italy and decentralized ones in the United Kingdom, Lithuania and Latvia. The different models have been described in detail, identifying the entities supervising the discussed type of entreprises.

Keywords: state enterprise, supervision, European Union, ownership

* Doktor nauk prawnych, ekspert ds. międzynarodowych BAS danuta.adamiec@sejm.gov.pl • https://orcid.org/0000-0002-6600-4309

**Ekspert ds. międzynarodowych BAS - justyna.branna@sejm.gov.pl . https://orcid.org/0000-0002-9653-9996

*** Doktor nauk humanistycznych, Uniwersytet Warszawski, ekspert ds. międzynarodowych BAS - dobromir.dziewulak@sejm.gov.pl • https://orcid.org/0000-0002-7974-8024

**** Ekspert ds. międzynarodowych BAS - kamila.groszkowska@sejm.gov.pl https://orcid.org/0000-0002-8618-1302

**** Doktor nauk humanistycznych, ekspert ds. międzynarodowych BAS marcin.mroz@sejm.gov.pl • https://orcid.org/0000-0001-5033-2132

****** Ekspert BAS ds. międzynarodowych - lukasz.zoladek@sejm.gov.pl • https://orcid.org/0000-0001-5247-6228

Analiza systemów nadzoru właścicielskiego nad przedsiębiorstwami państwowymi w wybranych państwach Unii Europejskiej (Czechy, Finlandia, Francja, Hiszpania, Litwa, Łotwa, Niemcy, Wielka Brytania, Włochy) sporządzona 19 kwietnia 2019 r. na zlecenie posła Klubu Parlamentarnego Platforma Obywatelska - Koalicja Obywatelska; BAS-ZSP 347/19. 


\section{Wstęp}

Zgodnie ze standardami Organizacji Współpracy Gospodarczej i Rozwoju (Organisation for Economic Cooperation and Development, OECD) do przedsiębiorstw państwowych zaliczane są tylko przedsiębiorstwa prowadzące działalność gospodarczą, w związku z czym z zakresu definicji wyłączone są podmioty spełniające funkcję administracyjną lub związaną $\mathrm{z}$ wykonywaniem władzy publicznej. OECD zaproponowała podział przedsiębiorstw państwowych na cztery grupy podmiotów: podmioty notowane na giełdzie $\mathrm{z}$ większościowymi udziałami państwa, podmioty notowane na giełdzie z mniejszościowymi udziałami państwa, przedsiębiorstwa nienotowane na giełdzie funkcjonujące na podstawie zasad prawa handlowego oraz podmioty, których jedynym właścicielem jest państwo, funkcjonujące na podstawie ustaw szczególnych.

Sposób organizacji nadzoru właścicielskiego nad przedsiębiorstwami w wybranych państwach przedstawiono poniżej.

W CzeCHACH nie ma jednego podmiotu, który prowadziłby nadzór właścicielski nad przedsiębiorstwami państwowymi. Prawa i obowiązki państwa jako właściciela $\mathrm{w}$ odniesieniu do przedsiębiorstw państwowych wykonują ministerstwa. W spółkach akcyjnych z udziałem państwa ministerstwa wykonują prawa akcjonariusza. Szczególną rolę w tym zakresie pełni Ministerstwo Finansów, które odpowiada za gospodarowanie majątkiem państwa, w tym kształtuje ogólną politykę właścicielską państwa (dualny system nadzoru). W FinLANDII przedsiębiorstwa państwowe w większości działają na podstawie ogólnych przepisów ustawy o spółkach z ograniczoną odpowiedzialnością, a jeśli ich akcje są notowane na giełdzie, również ustawy o rynku papierów wartościowych. Nadzór nad nimi ma charakter scentralizowany i sprawuje go przede wszystkim Urząd Premiera. We FrancJI system nadzoru właścicielskiego nad przedsiębiorstwami państwowymi realizowany jest przez rządową Agencję ds. Zarządzania Majątkiem (APE), podlegającą ministrowi finansów. APE jest odpowiedzialna za opracowywanie propozycji strategii dla spółek przez nią nadzorowanych oraz monitorowanie sytuacji finansowej i ekonomicznej tych spółek. W HiszPani nadzór właścicielski nad sektorem przedsiębiorstw państwowych ma charakter scentralizowany. Sektor przedsiębiorstw publicznych obejmuje: przedsiębiorstwa - jednostki publiczne, państwowe spółki handlowe oraz wszelkie instytucje i jednostki prawa publicznego związane lub zależne od administracji ogólnej państwa, konsorcja i fundusze niemające osobowości prawnej i nie włączone do sektora publicznego administracyjnego. $\mathrm{Za}$ administrowanie prawami finansów publicznych ustawowo odpowiada Ministerstwo Finansów i instytucje autonomiczne. Na LiTwIE wykonywanie nadzoru właścicielskiego nad przedsiębiorstwami państwowymi ma charakter zdecentralizowany. Nadzór realizowany jest przede wszystkim przez ministerstwa. Równocześnie w Ministerstwie Gospodarki wyodrębniona została agencja monitorująca i prognozująca pod nazwą Centrum Koordynacji Zarządzania, którego zadaniem 
jest monitorowanie i dokonywanie analiz w zakresie zarządzania przedsiębiorstwami państwowymi. Na ŁoTwIE istnieją dwie podstawowe formy prawne przedsiębiorstw państwowych: spółki z ograniczoną odpowiedzialnością oraz spółki akcyjne. Ponadto istnieje jeden podmiot o odrębnym charakterze - narodowa instytucja finansowa Altum. Nadzór nad przedsiębiorstwami państwowymi ma charakter zdecentralizowany. Wykonywanie praw i obowiązków państwa w obszarze nadzoru właścicielskiego powierzono ministerstwom według ich zakresu branżowego. Całość koordynuje Międzyresortowe Centrum Koordynacji. W Niemczech model nadzoru nad udziałami państwowymi jest połączeniem modelu zdecentralizowanego i dualnego. Regulacje dotyczące zarządzania udziałami państwa federalnego w przedsiębiorstwach prawa prywatnego zawarte są w dokumencie rządu federalnego zatytułowanym „Podstawy dobrego zarządzania przedsiębiorstwami i udziałami Federacji”. Federalne Ministerstwo Finansów sprawuje ogólną kontrolę finansową nad całością sektora państwowego, a także określa podstawowe wytyczne dotyczące funkcjonowania sektora przedsiębiorstw państwowych, które realizowane są przez odpowiednie resorty branżowe. W WIELKIEJ BRYTANII przedsiębiorstwa państwowe są tworzone i funkcjonują na podstawie kilku różnych form prawnych. Nadzór właścicielski ma charakter zdecentralizowany. Zadania związane ze sprawowaniem nadzoru właścicielskiego są podzielone między różne organy. Przedsiębiorstwa państwowe są nadzorowane przez właściwych ministrów zgodnie z zakresem branżowym - w przypadku części przedsiębiorstw nadzór sprawuje jeden minister, w przypadku innych nadzór jest sprawowany wspólnie przez dwóch lub kilku ministrów. Ponadto pewna grupa przedsiębiorstw państwowych jest nadzorowana przez powołaną specjalnie w tym celu agencję. We WŁoszecH obecny system nadzoru właścicielskiego ma charakter dualny. Charakteryzuje się on podziałem obowiązków właścicielskich między organy centralne (np. premiera, Ministerstwo Gospodarki i Finansów lub inne ministerstwa) a inne organy o charakterze sektorowym. W modelu włoskim nadzór organizacyjny w zakresie ogólnej polityki właścicielskiej i kontroli finansowej sprawowany jest przez Departament Skarbu w Ministerstwie Gospodarki i Finansów oraz przez ministerstwa resortowe.

Poniżej przedstawiono informacje szczegółowe dotyczące nadzoru właścicielskiego nad przedsiębiorstwami państwowymi w wybranych państwach Unii Europejskiej.

\section{Czechy}

W Czechach działają 102 przedsiębiorstwa państwowe. Ich obrót przekracza 563 mld koron rocznie ${ }^{2}$. Mają one formę przedsiębiorstw państwowych prowadzą-

2 Dane za: P. Bouda, M. Fadrný, Správa a řizení státem vlastněných podniků ve Velké Británii a v České republice. Inspirace pro změnu, Brno 2015, s. 7. 
cych działalność na podstawie przepisów ustawy o przedsiębiorstwie państwowym (39 przedsiębiorstw) lub spółek akcyjnych z udziałem państwa (63 spółki), które co do zasady działają według ogólnych przepisów ustawy o spółkach handlowych ${ }^{3}$. W Czechach nie ma jednego podmiotu, który prowadziłby nadzór właścicielski nad przedsiębiorstwami państwowymi. Prawa i obowiązki państwa jako właściciela w odniesieniu do przedsiębiorstw państwowych wykonują ministerstwa. W spółkach akcyjnych z udziałem państwa ministerstwa wykonują prawa akcjonariusza. Szczególną rolę w tym zakresie pełni Ministerstwo Finansów, które odpowiada za gospodarowanie majątkiem państwa, w tym kształtuje ogólną politykę właścicielską państwa (dualny system nadzoru ${ }^{4}$ ).

W Czechach przedsiębiorstwa państwowe (státní podniky) prowadzą działalność na podstawie przepisów ustawy nr 77/1997 o przedsiębiorstwie państwowym $^{5}$. Przedsiębiorstwo działa we własnym imieniu i na własną odpowiedzialność, prowadząc działalność gospodarczą w celu spełnienia istotnych interesów strategicznych, gospodarczych, społecznych, bezpieczeństwa lub innych interesów państwa ( $\$ 2$ ust. 1 ustawy). Przedsiębiorstwa państwowe nie mają własnego majątku i zarządzają majątkiem państwa ( $\$ 2$ ust. 2 ustawy). Organami przedsiębiorstwa państwowego są dyrektor (ředitel) oraz rada nadzorcza (dozorčí rada) ( $\$ 11$ ustawy). Założycielem przedsiębiorstwa jest państwo. W jego imieniu funkcję założyciela wykonuje ministerstwo, do którego zakresu branżowego należy dane przedsiębiorstwo, jeżeli ustawa nie stanowi inaczej. Do założenia przedsiębiorstwa konieczna jest uprzednia zgoda rządu ( $\$ 3$ ustawy).

Na mocy odrębnej ustawy nr 305/2000 o dorzeczach ${ }^{6}$ powołano pięć przedsiębiorstw państwowych (Povodí Labe, Povodí Moravy, Povodí Odry, Povodí Ohře oraz Povodí Vltavy), które prowadzą działalność w zakresie gospodarki wodnej. Miały one wcześniej formę spółek akcyjnych, które zostały zlikwidowa-

3 Dane za: Strategie vlastnické politiky státu, s. 11, https://www.mfcr.cz/assets/cs/media/ MFCR_Material_2017-01-18_Strategie-vlastnicke-politiky-statu.pdf.

4 OECD w raporcie Ownership and Governance of State-Owned Enterprises. A Compendium of National Practices z 2018 r. klasyfikuje czeski system nadzoru jako system dualny, wskazując na wiodącą rolę Ministerstwa Finansów. Ministerstwo Finansów Republiki Czeskiej w „Strategii polityki własnościowej państwa” z 2016 r. określa czeski system nadzoru jako zdecentralizowany.

5 Zákon č. 77/1997 Sb. o státním podniku, ze zm. Szczególną formę ma przedsiębiorstwo Budějovický Budvar, które jest przedsiębiorstwem narodowym (národní podnik). Przedsiębiorstwa narodowe były przedsiębiorstwami państwowymi w Czechosłowacji po II wojnie światowej, w latach 1988-1990 były prywatyzowane lub przekształcane w przedsiębiorstwa państwowe. Tę formę prawną zachował, jako jedyne przedsiębiorstwo, Budějovický Budvar. Ze względu na to, że planowana ustawa o przedsiębiorstwie narodowym nie została przyjęta, działa ono na podstawie przepisów ustawy nr 77/1997 o przedsiębiorstwie państwowym.

6 Zákon č. 305/2000 Sb., o povodích, ze zm. 
ne na mocy tej ustawy, a w ich miejsce powołano przedsiębiorstwa państwowe. Działają one na podstawie przywołanej wyżej ustawy nr 305/2000, a w zakresie przez nią nieuregulowanym - na podstawie przepisów ustawy nr 77/1997 o przedsiębiorstwie państwowym ${ }^{7}$.

Prawa i obowiązki państwa jako właściciela przedsiębiorstw państwowych wykonują ich założyciele, czyli ministerstwa. Te prawa i obowiązki zdefiniowano w $\$ 15$ ustawy nr 77/1997 o przedsiębiorstwie państwowym. Zgodnie z jego postanowieniami, założyciel m.in.:

- zakłada i likwiduje przedsiębiorstwo, wydaje decyzję o przekształceniu przedsiębiorstwa oraz określa w załączniku do aktu założycielskiego majątek przekazany przedsiębiorstwu,

- może zmieniać akt założycielski (nie dotyczy to pomniejszenia majątku, którym przedsiębiorstwo ma prawo gospodarować w chwili założenia go lub w chwili wpisu zmiany dokumentu założycielskiego do rejestru handlowego),

- w ciągu 3 miesięcy od dnia wpisania przedsiębiorstwa do rejestru handlowego nadaje przedsiębiorstwu statut, w którym określa, w jakich sytuacjach działania dyrektora wymagają uprzedniej zgody rady nadzorczej; w statucie zawarte są zasady dotyczące ukierunkowywania działalności gospodarczej przedsiębiorstwa, zasady prowadzenia działań kontrolnych przez założyciela i zasady zarządzania majątkiem przedsiębiorstwa,

- mianuje i odwołuje dyrektora (chyba że mianuje go rząd), członków rady nadzorczej i likwidatora,

- zatwierdza regulamin rady nadzorczej, określa liczbę jej członków, długość kadencji oraz minimalną liczbę zebrań w ciągu roku,

- ma prawo i obowiązek żądać informacji o działalności gospodarczej i stanie majątku przedsiębiorstwa oraz kontrolować i weryfikować te informacje w sposób wskazany w odrębnych przepisach (ustawa nr 255/2012 o kontroli ${ }^{8}$ ),

- kontroluje, czy potrzeby państwa, które przedsiębiorstwo zaspokaja swoją działalnością, są zapewniane w sposób celowy i gospodarny,

- zatwierdza sprawozdanie finansowe oraz raport roczny; decyduje o podziale zysku (rozliczeniu straty),

- kontroluje, czy przedsiębiorstwo należycie korzysta z prawa gospodarowania majątkiem państwa, w tym zwłaszcza, czy majątek ten jest wykorzystywany przy prowadzeniu działalności gospodarczej oszczędnie, wydajnie i skutecznie, oraz kontroluje, w jaki sposób przedsiębiorstwo rozporządza tym majątkiem.

7 Informacje za: J. Hroch, Státní podniky v České republice a v Evropě, https://www.kulturni-noviny.cz/nezavisle-vydavatelske-a-medialni-druzstvo/archiv/online/2015/46$-2015 / 5648 \mathrm{fbb} 1 \mathrm{f} 147 \mathrm{~d}$.

8 Zákon č. 255/2012 Sb., o kontrole (kontrolní řád), ze zm. 
Założyciel przy wykonywaniu wyżej wymienionych czynności zobowiązany jest działać $\mathrm{z}$ należytą starannością.

Nadzór właścicielski państwa nad spółkami z udziałem państwa uregulowano w ustawie nr 219/2000 o majątku Republiki Czeskiej i występowaniu przez nią w stosunkach prawnych ${ }^{9}$. Zgodnie $\mathrm{z} \$ 28$ ust. 1 tej ustawy państwo może zakładać tylko spółki akcyjne (lub uczestniczyć w ich założeniu). Działają one na podstawie ogólnych przepisów (ustawa nr 90/2012 o spółkach handlowych i spółdzielniach $)^{10}$. Co do zasady, władze spółki akcyjnej są tworzone zgodnie z modelem systemu dualistycznego (organami spółki są zarząd i rada nadzorcza, powoływane przez walne zgromadzenie). Na giełdzie notowana jest tylko jedna spółka akcyjna kontrolowana przez państwo (spółka ČEZ a.s. działająca w branży energetycznej) - podlega ona zatem także przepisom ustawy nr 256/2004 o prowadzeniu działalności na rynku kapitałowym ${ }^{11}$.

Zgodnie z $\$ 28$ ustawy nr 219/2000 o majątku Republiki Czeskiej i występowaniu przez nią w stosunkach prawnych, do utworzenia spółki akcyjnej przez państwo (lub wzięcia udziału w jej utworzeniu) konieczna jest uprzednia zgoda rządu.

W imieniu państwa funkcję założyciela spółki akcyjnej pełni ministerstwo, ono także wnosi aktywa do spółki. Zgodnie z $\$ 4$ ust. 1 ustawy nr 2/1969 o utworzeniu ministerstw $i$ innych centralnych organów administracji państwowej organem administracji państwowej odpowiedzialnym za gospodarowanie majątkiem państwa jest Ministerstwo Finansów. Odgrywa ono wiodącą rolę jako podmiot wykonujący prawa akcjonariusza w spółkach akcyjnych z udziałem państwa (Ministerstwo Finansów wykonuje te prawa w odniesieniu do 51 spółek). Funkcję tę mogą także pełnić inne ministerstwa (rolnictwa, spraw wewnętrznych, transportu, przemysłu i handlu, obrony, kultury, zdrowia czy ministerstwo ds. rozwoju) - dotyczy to łącznie 12 spółek $^{12}$. Minister finansów w dyrektywie nr 3/2015 z 4 marca 2016 r. określił zasady wykonywania przez państwo praw w spółkach $\mathrm{z}$ udziałem Republiki Czeskiej o strategicznym znaczeniu ${ }^{13}$. Wskazuje w nich, w jaki sposób mają wykonywać swoje obowiązki przedstawiciele Ministerstwa

9 Zákon č. 219/2000 Sb., o majetku České republiky a jejím vystupování v právnich vztazích, ze zm. Szczególną pozycję ma spółka akcyjna Koleje Czeskie (České dráhy, a. s.), która działa na mocy odrębnej ustawy nr 77/2002 o spółce akcyjnej Koleje Czeskie i o organizacji państwowej Administracja Infrastruktury Kolejowej (Zákon č. 77/2002 o a. s. České dráhy, státní organizaci Správa železniční dopravní cesty, ze zm.)

10 Zákon č. 90/2012 o obchodních společnostech a družstvech (zákon o obchodních korporacích), ze zm.

11 Zákon č. 256/2004 Sb., o podnikání na kapitálovém trhu, ze zm.

12 Informacje za: P. Bouda, M. Fadrný, Správa a ř́zení státem, op. cit, s. 13, oraz Strategie vlastnické politiky státu, s. 11.

13 Smèrnice č. 3/2015 ministra financí - Pravidla pro výkon vlastnických práv státu v obchodních korporacích strategického významu s majetkovou účastí České republiky. 
Finansów (m.in. dotyczą one zasad postępowania przez przedstawiciela podczas walnego zgromadzenia i w organach spółek).

Prawa akcjonariusza w spółce akcyjnej w imieniu państwa są wykonywane przez wyznaczonego przez rząd pracownika ministerstwa, które założyło spółkę. Pracownik ten ma obowiązek postępować zgodnie z przepisami prawa i pisemnymi instrukcjami ministra oraz regularnie, w wyznaczonych terminach, przekazywać ministrowi pisemne sprawozdania ( $\$ 28$ ust. 2 ustawy nr 219/2000).

W 2014 r. w Czechach utworzono Rządową Komisję ds. Nominacji Personalnych ${ }^{14}$, składającą się z trzech członków mianowanych przez rząd. Jest ona organem doradczym rządu odpowiedzialnym za ocenę osób, które mają reprezentować państwo w radach nadzorczych spółek z udziałem państwa, przedsiębiorstw państwowych i przedsiębiorstwa narodowego. Opinia komisji nie ma charakteru wiążącego.

Zasady wynagradzania członków rad nadzorczych spółek akcyjnych z udziałem państwa oraz przedsiębiorstw państwowych zostały przyjęte przez rząd uchwałą nr 159 z 2010 r. ${ }^{15}$. Zgodnie z informacjami zawartymi w „Strategii polityki właścicielskiej państwa” (patrz niżej) zasady te nie były w pełni przestrzegane. W związku z tym w 2015 r. przyjęto zaktualizowane zasady w tym zakresie, w celu usunięcia wątpliwości interpretacyjnych. Obecnie trwają prace nad projektem ustawy o wyborze osób do organów zarządzających i nadzorujących osób prawnych z udziałem państwa (ustawa o nominacjach) ${ }^{16}$.

W Czechach - jak informował pod koniec 2015 r. czeski Najwyższy Urząd Kontroli (Nejvyšší kontrolní úřad) ${ }^{17}$ - nie było spójnej polityki właścicielskiej państwa. Najwyższy Urząd Kontroli wskazywał, że nie przyjęto dokumentu, w którym zostałyby określone średnio- i długoterminowe cele przedsiębiorstw państwowych. W 2012 r. zlecono wprawdzie opracowanie takiego dokumentu, jednak termin realizacji był wielokrotnie przekładany. W „Planie działań w zakresie zwalczania korupcji na 2016 rok” ${ }^{18}$, przyjętym na podstawie „Rządowej koncepcji walki z korupcją na lata 2015-2017”19, zlecono Ministerstwu Finansów przygotowanie projektu długoterminowej strategii wykonywania praw właś-

14 Vládní výbor pro personální nominace, https://www.vlada.cz/cz/ppov/vladni-vybor-pro-personalni-nominace-117326/.

15 Usnesení vlády č. 159 - Zásady odměňování vedoucích zaměstnanců a členů orgánu obchodních společností s majetkovou účastí státu.

16 Návrh zákona o výběru osob do řídících a dozorčích orgánů právnických osob s majetkovou účastí státu (nominační zákon).

17 Informacja dostępna na stronie: https:/www.nku.cz/cz/pro-media/tiskove-zpravy/ vlastnicka-politika-statu-uz-roky-chybi--ceska-republika-tak-stale-nema-jasno--se-kterymi-spolecnostmi-s-majetkovym-podilem-statu-do-budoucna-pocita-id5579/.

18 Akční plán boje s korupcí pro rok 2016.

19 Vládní koncepce boje s korupcí na léta 2015 až 2017. 
ciciela przez państwo, w tym podstawowych celów i roli państwa w zarządzaniu i nadzorze przedsiębiorstw państwowych i spółek akcyjnych z udziałem państwa.

W 2016 r. Ministerstwo Finansów opracowało, zgodnie z zaleceniem OECD, "Strategię polityki właścicielskiej państwa" ${ }^{20}$, jednak dokument ten na posiedzeniu rządu w dniu 16 stycznia 2017 r. nie został przyjęty ${ }^{21}$. Powołując się na zalecaną przez OECD centralizację nadzoru, Ministerstwo Finansów zaleciło poprawę koordynacji funkcji nadzorczych między wykonującymi je ministerstwami oraz ustanowienie jednolitych zasad w tym zakresie. Ministerstwo zaleciło także zdefiniowanie i wskazanie "przedsiębiorstw strategicznych” dla państwa, a na tej podstawie wskazanie podmiotów, które należałoby sprywatyzować lub zlikwidować.

Zgodnie z przywołaną wyżej "Strategią polityki właścicielskiej państwa” z 2016 r. polityka ta powinna przewidywać rolę państwa, które:

- jest wymagającym i aktywnym właścicielem,

- nie ingeruje w zarządzanie przedsiębiorstwem,

- jako właściciel stara się odpolitycznić i zmaksymalizować profesjonalizację organów zarządzających i kontrolnych; państwo powinno wymagać specjalistycznej wiedzy, profesjonalizmu i wysokich standardów etycznych w odniesieniu do działalności osób w organach przedsiębiorstw/spółek oraz nominować te osoby w sposób uporządkowany i przejrzysty,

- jako właściciel formułuje jasne cele strategiczne oraz krytycznie ocenia proponowane strategie biznesowe,

- stosuje taką politykę w zakresie wynagrodzeń, aby móc przyciągnąć wysokiej klasy specjalistów, równocześnie jednak gwarantuje, że ich wynagrodzenia czy inne warunki związane z wykonywaniem funkcji nie są ponadstandardowe,

- monitoruje i ocenia wyniki przedsiębiorstw/spółek, wykorzystując porównania sektorowe i międzynarodowe do oceny wydajności,

- formułuje politykę w zakresie dywidend, która jest stabilna i odzwierciedla rzeczywiste możliwości spółek,

- kładzie nacisk na przejrzystość (informacje o poszczególnych przedsiębiorstwach/spółkach i kluczowych wskaźnikach są publicznie dostępne; roczne sprawozdania z zarządzania zawierające dane dla poszczególnych przedsiębiorstw/ spółek są udostępniane opinii publicznej po ich zatwierdzeniu przez rząd).

W ramach realizacji „Rządowej koncepcji walki z korupcją na lata 20182022 "22 rząd przyjął plany działań w zakresie zwalczania korupcji na lata 2018

20 Strategie vlastnické politiky státu, https://www.mfcr.cz/assets/cs/media/MFCR_Material_2017-01-18_Strategie-vlastnicke-politiky-statu.pdf.

${ }^{21}$ MF odmitá deklarované di̊vody neschválení Strategie vlastnické politiky státu, https:// www.mfcr.cz/cs/aktualne/tiskove-zpravy/2017/mf-odmita-deklarovane-duvody-neschvaleni-27321.

22 Vládní koncepce boje s korupcí na léta 2018 až 2022. 
i $2019^{23}$, w których zawarto, jako jeden z czterech priorytetowych obszarów, racjonalne zarządzanie majątkiem państwa. Rząd przewiduje kontynuowanie prac nad projektem ustawy o wyborze osób do organów zarządzających i nadzorujących osób prawnych z udziałem państwa, nie wspomina jednak o przyjęciu strategii polityki właścicielskiej państwa.

\section{Finlandia}

W Finlandii działa 67 przedsiębiorstw państwowych ${ }^{24}$ (stan na 28 lutego 2019 r. $)^{25}$, z czego większość w sektorze energii, finansów oraz dóbr i usług przemysłowych. $65 \mathrm{z}$ nich to spółki, które działają na gruncie ogólnych przepisów ustawy o spółkach z ograniczoną odpowiedzialnością ${ }^{26}$, a jeśli ich akcje są notowane na giełdzie, również ustawy o rynku papierów wartościowych ${ }^{27}$. Nadzór nad nimi ma charakter scentralizowany. Instytucją pełniącą nadzór jest przede wszystkim Urząd Premiera, z wyłączeniem niektórych tzw. spółek specjalnego przeznaczenia (zob. niżej), nad którymi pieczę sprawują poszczególne minister$s \mathrm{st}^{28}$. W Finlandii funkcjonują równolegle dwa przedsiębiorstwa państwowe, działające na podstawie przepisów odrębnych ustaw, pod nadzorem odrębnych ministerstw.

Ogólne uregulowania dotyczące nadzoru właścicielskiego nad spółkami, w których państwo posiada udziały/akcje, zawarto w ustawie o własności państwowej i ładzie korporacyjnym ${ }^{29}$. Natomiast szczegóły nadzoru właścicielskiego określane są przez rząd na początku kadencji w rozporządzeniu. Ostatnie takie rozporządzenie z 2016 r. określa cele państwa w zakresie nadzoru właścicielskie-

23 Uchwała rządu nr 170 z 11 marca 2019 r. - Akční plán boje s korupcí na rok 2019 oraz uchwała rządu nr 11 z 3 stycznia 2018 r. - Akční plán boje s korupcí na rok 2018, https://korupce.cz/protikorupcni-dokumenty-vlady/na-leta-2018-az-2022/2019-2/.

24 Przedsiębiorstwo państwowe definiowane jako podmiot gospodarczy, nad którym państwo sprawuje kontrolę korporacyjną i który znaczną część przychodów uzyskuje ze sprzedaży dóbr i usług o charakterze rynkowym, za: M. Bałtowski, G. Kwiatkowski, Przedsiębiorstwa państwowe we wspótczesnej gospodarce, Warszawa 2018. dings-and-parliamentary-authorisations. Osakeyhtiölaki, 624/2006, ze zm.

27 Arvopaperimarkkinalaki, 746/2012, ze zm.

28 Report on State Annual Accounts 2017. Annex 4 State corporate holdings, Government of Finland, 23/2018, http://julkaisut.valtioneuvosto.fi/bitstream/handle/10024/160934/23_18_Report_on_State_Annual_Accounts_2017_Annex4_State_corporate_holdings_web.pdf?sequence $=1$ \&isAllowed $=\mathrm{y}$.

29 Laki valtion yhtiöomistuksesta ja omistajaohjauksesta, 1368/2007, ze zm. 
go, na podstawie programu rządu do $2025 \mathrm{r}^{30}$. W załączniku do rozporządzenia znajduje się lista wszystkich spółek z udziałem państwa wraz z informacją o minimalnym udziale zatwierdzonym przez parlament, aktualnym udziale państwa oraz ministerstwie sprawującym nadzór.

Na gruncie ustawy o własności państwowej i ładzie korporacyjnym wyodrębniono dwie formy spółek: spółki z większościowym udziałem państwa ( $\mathrm{val}$ tioenemmistöisellä yhtiöllä) oraz spółki stowarzyszone (valtion osakkuusyhtiöllä), w których państwo ma co najmniej 10\% i nie więcej niż 50\% udziałów/akcji. Jeśli państwo ma w spółce mniej niż 10\% udziałów/akcji, może być ona uznana za spółkę stowarzyszoną w rozporządzeniu rządu, jeśli jest to konieczne z punktu widzenia interesów finansowych lub ładu korporacyjnego. Ponadto w $2016 \mathrm{r}$. wprowadzono do ustawy o własności państwowej i ładzie korporacyjnym odrębną kategorię spółki, tzw. państwową spółkę rozwoju (valtion kehitysyhtiöllä). Spółka ta, z większościowym udziałem państwa, tworzy spółki, jest ich właścicielem oraz administruje nimi, a także nabywa i zbywa udziały/akcje spółek. Spółka taka, Vake, rozpoczęła swoją działalność w 2018 r. i posiada obecnie (stan na 29 marca 2019 r.) udziały w 5 spółkach, z najbliższymi planami przejęcia udziałów $\mathrm{w}$ dwóch kolejnych spółkach ${ }^{31}$. Jej celem jest zwiększenie efektywności inwestycji państwa w spółkach ważnych z punktu widzenia interesu finansowego państwa.

Ponadto część spółek ma charakter spółek o szczególnych przeznaczeniu, czyli przyznano im szczególne funkcje np. na mocy odrębnych ustaw. Przykładem takiej spółki jest Finnvera, utworzona na podstawie ustawy o państwowej wyspecjalizowanej spółce finansującej ${ }^{32}$, która oferuje finansowanie na założenie i rozwój przedsiębiorstw, a także wspieranie ich działalności eksportowej.

Jedną ze spółek o szczególnym przeznaczeniu jest utworzona w 2008 r. Solidium Oy ze 100\% udziałem państwa, której misją jest efektywniejsze zarządzanie aktywami państwa. Jest ona mniejszościowym udziałowcem w spółkach notowanych na giełdzie (lub planujących wejście na giełdę) ważnych z punktu widzenia interesu państwa (np. gospodarczego, infrastrukturalnego, bezpieczeństwa dostaw).

Zgodnie z rozporządzeniem rządu w sprawie polityki nadzoru właścicielskiego można więc wskazać cztery grupy spółek, nad którymi w różny sposób nadzór właścicielski sprawuje departament w Urzędzie Premiera:

- państwowa spółka rozwoju Vake,

- Solidium Oy, jako akcjonariusz mniejszościowy w spółkach ważnych z punktu widzenia interesu państwa,

- 19 spółek ważnych z punktu widzenia interesu państwa,

30 Government Resolution on State-Ownership Policy, 13 May 2016, https://vnk.fi/documents/10616/1221497/Periaatep_2016_korjENG.pdf/b5c9155f-c559-4c5b-b4499eb8f5d54f30/Periaatep_2016_korjENG.pdf.pdf/Periaatep_2016_korjENG.pdf.pdf.

31 Informacje ze strony internetowej spółki Vake: https://vake.fi/envake/.

32 Laki valtion erityisrahoitusyhtiöstä, 443/1998, ze zm. 
- ponad 30 spółek o szczególnym przeznaczeniu, z czego spółki ważne z punktu widzenia interesów handlowych nadzorowane są przez Urząd Premiera, a pozostałe przez poszczególne ministerstwa ${ }^{33}$.

Jeśli chodzi o podział zadań w zakresie nadzoru właścicielskiego, to zgodnie z ustawą o własności państwowej i ładzie korporacyjnym, co do zasady, parlament musi wyrazić zgodę na decyzje, które skutkowałyby pozbawieniem państwa wyłącznego lub większościowego udziału w spółce, a także objęciem przez państwo większościowego udziału w spółce, $\mathrm{z}$ wyjątkiem małych i średnich spółek (art. 3 ust. 1 i 2 ustawy). $Z$ kolei rząd kolegialnie podejmuje decyzje m.in. w zakresie (art. 4 ustawy):

- nabycia i zbycia udziałów w spółkach,

- fuzji i podziałów spółek, które skutkują zmianą w udziale państwa o co najmniej 5\% lub wiążącą się ze zmianami we wpływie na decyzje,

- likwidacji spółek,

- inwestycji,

- ogólnych zasad nadzoru właścicielskiego.

Zgodnie z art. 5 ustawy o własności państwowej i ładzie korporacyjnym ministerstwa odpowiedzialne za nadzór nad poszczególnymi spółkami podejmują decyzje w zakresie m.in. nominacji przedstawicieli państwa na walne zgromadzenie spółki i udzielenia mu wytycznych oraz w zakresie realizacji praw państwa jako udziałowca.

W Finlandii równolegle funkcjonują dwa przedsiębiorstwa państwowe (valtion liikelaitoksista), działające na podstawie przepisów odrębnych ustaw. Pierwsze Senaatti-kiinteistöt - utworzone na mocy ustawy o przedsiębiorstwach państwowych $^{34}$, działające pod nadzorem Ministerstwa Finansów, jest odpowiedzialne za zarządzanie nieruchomościami państwa. Drugie - Metsähallitus - utworzone na podstawie odrębnej ustawy o Metsähallitus ${ }^{35}$, to przedsiębiorstwo działające pod nadzorem Ministerstwa Rolnictwa i Leśnictwa ${ }^{36}$, odpowiedzialne jest za zarządzanie państwowymi zasobami lądowymi i wodnymi ${ }^{37}$. Oba przedsiębiorstwa państwowe mogą posiadać udziały/akcje w spółkach działających na gruncie

33 Szczegółowy podział, wraz z informacją, które spółki wchodzą do której grupy, można znaleźć na stronie internetowej Urzędu Premiera: https://vnk.fi/en/companies.

34 Laki valtion liikelaitoksista, 1062/2010, ze zm.

35 Laki Metsähallituksesta, 1378/2004, ze zm.

36 W sprawach z zakresu ochrony przyrody przedsiębiorstwo Metsähallitus nadzorowane jest przez Ministerstwo Środowiska.

37 W przedsiębiorstwie Metsähallitus działalność gospodarcza i administracyjna są rozdzielone, co przejawia się m.in. w osobnej rachunkowości i sprawozdaniach finansowych. Więcej informacji na stronie internetowej przedsiębiorstwa Metsähallitus: http://www.metsa.fi/web/en/managementandadministrationsystem. 
ogólnych przepisów ustawy o spółkach z ograniczoną odpowiedzialnością (art. 18 ustawy o przedsiębiorstwach państwowych oraz art. 4 ustawy o Metsähallitus).

Organami w obu przedsiębiorstwach są zarząd, powoływany przez Ministerstwo Finansów w przypadku Senaatti-kiinteistöt, oraz rząd w przypadku Metsähallitus, oraz dyrektor zarządzający, wybierany przez zarząd (art. 7 i 9 ustawy o przedsiębiorstwach państwowych oraz art. 11 i 14 ustawy o Metsähallitus).

Zgodnie z art. 6 ustawy o przedsiębiorstwach państwowych oraz art. 8 i 9 ustawy o Metsähallitus, po zatwierdzeniu budżetu państwa, w którym przyznane są środki dla obu przedsiębiorstw państwowych, nadzorujące ministerstwa ustalają zakres działań przedsiębiorstw, cele operacyjne oraz zakres zysków. Parlament zatwierdza zmiany w wysokości kapitału podstawowego i decyduje o alokacji budżetowej na jego zwiększenie, udziela zgody na zaciągnięcie pożyczek na finansowanie działalności przedsiębiorstwa, a także zatwierdza maksymalną kwotę inwestycji na dany rok oraz upoważnia do zaciągania zobowiązań dotyczących inwestycji, które będą generować wydatki na kolejne lata.

Rząd podejmuje m.in. następujące decyzje:

- powołuje zarząd (w przypadku Metsähallitus),

- zatwierdza sprawozdania finansowe,

- co do zasady podejmuje decyzje o transferach między przedsiębiorstwem państwowym a budżetem państwa,

- zatwierdza zakup lub zbycie udziałów/akcji w spółkach, w których przedsiębiorstwo posiada udziały/akcje.

Odpowiedzialne ministerstwa decydują natomiast np. o celach operacyjnych oraz w sprawie zysków, w ramach wyznaczonych przez parlament, o wysokości wynagrodzeń członków zarządu czy o niektórych transferach między przedsiębiorstwem państwowym a budżetem państwa.

\section{Francja}

Sektor przedsiębiorstw państwowych jest we Francji jednym z największych wśród krajów wysoko rozwiniętych ${ }^{38}$. Państwowe wsparcie sektora gospodarczego odegrało istotną rolę w gospodarczej historii Francji. Historycy uznają, że pierwsze przedsiębiorstwa państwowe w obecnym rozumieniu powstały we Francji już w XV wieku, przy czym centralizacja zasobów gospodarczych uwidoczniła się w pełni w czasie rządów Ludwika XIV i jego ministra finansów Jeana-Baptiste Colberta $^{39}$. Wiek XX był we Francji czasem dynamicznego powiększania sektora

38 M. Bałtowski, G. Kwiatkowski, Przedsiębiorstwa państwowe, op. cit., s. 107.

39 M. Somai, Ewolucja interwencji państwa w gospodarke - na przykładzie Francji i Stowenii, „Studia Ekonomiczne” 2016, nr 4, s. 604. 
przedsiębiorstw państwowych. Pierwsza fala nacjonalizacji związana była z przejęciem władzy przez Front Ludowy, druga miała miejsce po II wojnie światowej, wymuszona koniecznością odbudowania państwa, a trzecia przypadła na początek lat 80. XX wieku. Na mocy ustawy nacjonalizacyjnej z 11 lutego 1982 r. państwo przejęło pięć dużych grup przemysłowych, kilkadziesiąt banków oraz dwie spółki z sektora finansowego. Polityka nacjonalizacyjna tamtego okresu była ukierunkowana przede wszystkim na ochronę krajowej gospodarki przed negatywnymi skutkami globalizacji, jednakże nie przyniosła oczekiwanych efektów. Nacjonalizacja okazała się bardzo kosztowna dla francuskiej gospodarki, m.in. ze względu na duże nakłady przeznaczone na finansowanie nierentownych przedsiębiorstw oraz przerost zatrudnienia w sektorze publicznym. W konsekwencji pod koniec lat 80 . XX wieku rozpoczęły się wieloletnie procesy reprywatyzacyjne, trwające aż do pierwszej dekady XXI wieku.

W doktrynie francuskiej pojęcie przedsiębiorstwa państwowego (entreprise publique) jest rozumiane dość szeroko. Są to osoby prawne lub jednostki posiadające osobowość prawną, prowadzące działalność w zakresie produkcji dóbr lub świadczenia usług, podlegające władzom publicznym ${ }^{40}$.

Według danych z raportu The Size and Sectoral Distribution of State-Owned Enterprises przygotowanego przez OECD w roku 2017 ${ }^{41}$, obejmującego wszystkie analizowane państwa, największy udział przedsiębiorstw państwowych jest w sektorze finansowym - na poziomie 26\%, następnie energetyczno-gazowniczym - 26\% oraz transportowym - 18\%. We Francji przedsiębiorstwa państwowe działają przede wszystkim w sektorze przemysłowym, finansowym, telekomunikacyjnym, energetyczno-gazowniczym i transportowym. Ich liczba według autorów raportu OECD wynosi 61, w tym 4 spółki giełdowe z większościowymi udziałami państwa oraz 19 przedsiębiorstw państwowych funkcjonujących na szczególnych zasadach.

Dane te różnią się nieznacznie od tych przedstawionych w oficjalnych raportach rządowych. Zgodnie z raportem Agencji ds. Zarządzania Majątkiem ${ }^{42}$ państwo francuskie sprawuje nadzór nad 81 przedsiębiorstwami, o łącznej sumie dochodów za rok 2017 w wysokości 509,5 mld euro. Są to przede wszystkim przedsiębiorstwa $z$ sektora energetycznego, przemysłu, finansowego i usług oraz transportowego. Zgodnie z danymi z 2018 r. państwo francuskie posiada udziały w 12 przedsiębiorstwach notowanych na giełdzie o łącznej wartości 77,5 mld euro.

40 F. Grzegorczyk, Przedsiębiorstwo publiczne kontrolowane przez państwo - zagadnienia konstrukcyjne, Warszawa 2012, s. 144.

${ }^{41}$ OECD, The Size and Sectoral Distribution of State-Owned Enterprises, https://read. oecd-ilibrary.org/governance/the-size-and-sectoral-distribution-of-state-owned-enterprises_9789264280663-en\#page50.

42 Agence des Participations de l'État, Rapport d'Activité 2017-2018, https://www.economie.gouv.fr/files/files/directions_services/agence-participations-etat/Documents/ Rapports-de-1-Etat-actionnaire/2017/Rapport_Etat_Actionnaire_2017-2018.pdf. 


\section{Wykres 1. Główne udziały państwa w przedsiębiorstwach francuskich - zależność między wysokością dochodów (w mld euro) w 2017 r. a procentowym udziałem własności państwowej}

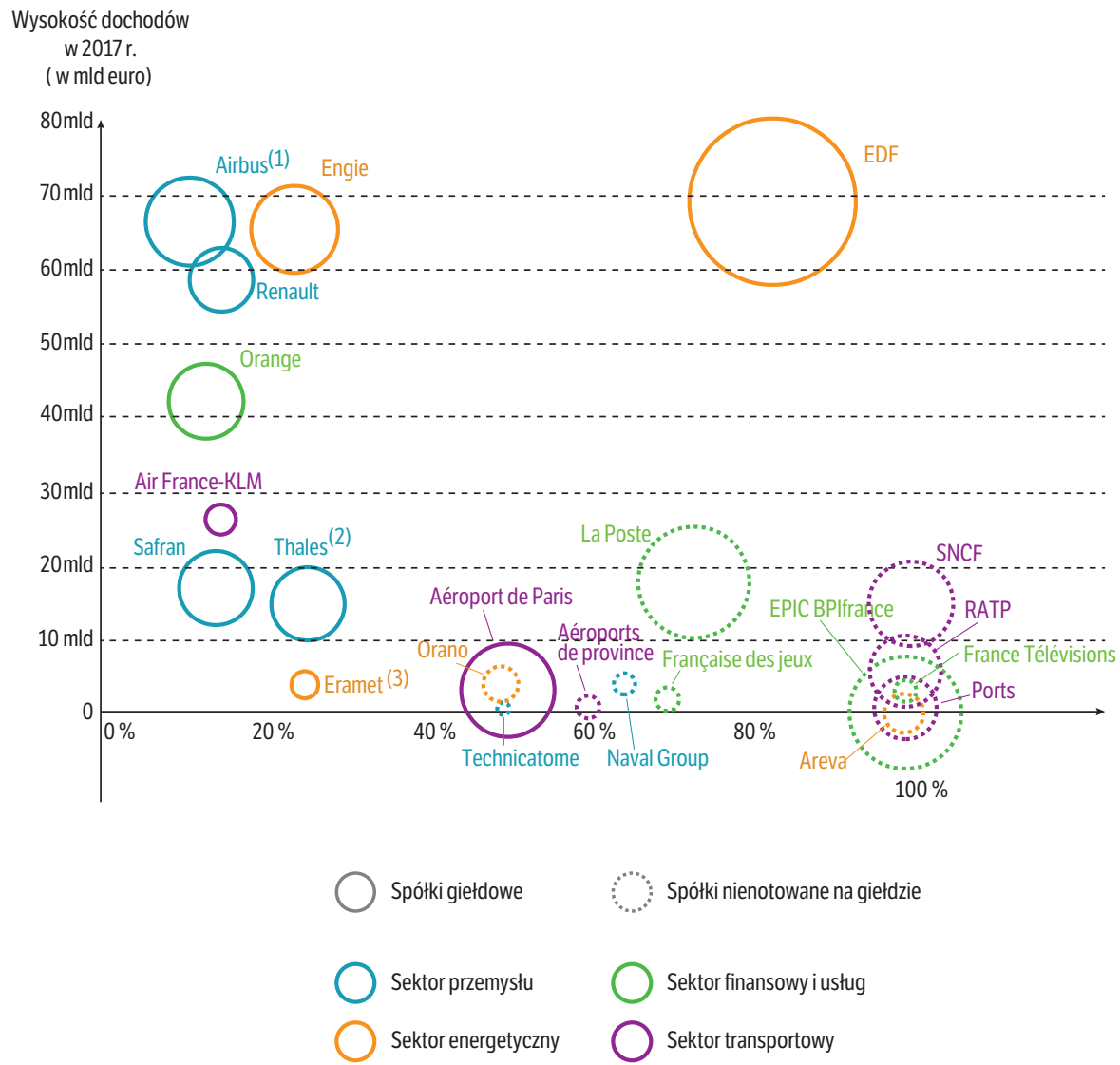

Uwaga: rozmiar koła jest proporcjonalny do wartości rynkowej udziału państwa w spółkach giełdowych oraz do wartości udziału państwa w kapitale własnym spółki w spółkach nienotowanych na giełdzie.

Źródło: Agence des Participations de l'État, Rapport d’Activité 2017-2018.

Znaczenie sektora przedsiębiorstw państwowych w gospodarce najczęściej rozumiane jest jako udział przedsiębiorstw tego sektora w grupie najważniejszych przedsiębiorstw w danym kraju, w branżach uznawanych za strategiczne (tj. finansowej, energetycznej czy zbrojeniowej) ${ }^{43}$. Ze względu na rozbieżności definicyjne i metodologiczne nie ma jednego sposobu badania zakresu i zna-

43 M. Bałtowski, G. Kwiatkowski, Przedsiębiorstwa państwowe, op. cit., s. 251. 
Wykres 2. Wysokość udziałów państwa w przedsiębiorstwach notowanych na giełdzie w czerwcu 2018 r. ( $w$ mln euro oraz $w \%)$
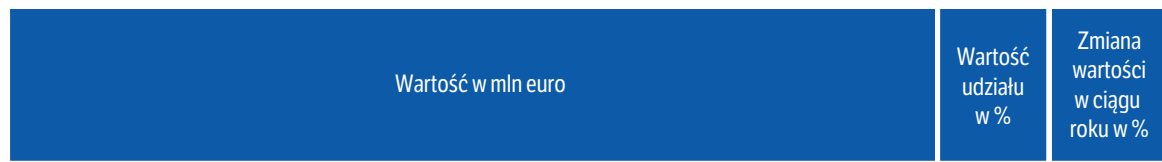

\begin{tabular}{|c|c|c|c|}
\hline EDF & $\begin{array}{ll} & 29688\end{array}$ & $83,7 \%$ & $+24,2 \%$ \\
\hline ADP & 9706 & $50,6 \%$ & $+37,1 \%$ \\
\hline Airbus & 8606 & $11,1 \%$ & $+39,3 \%$ \\
\hline Engie & 7705 & $24,1 \%$ & $(0,6 \%)$ \\
\hline Safran & 6076 & $13,2 \%$ & $+29,7 \%$ \\
\hline Thalès & 6046 & $25,7 \%$ & $+17,1 \%$ \\
\hline Orange & 5110 & $13,4 \%$ & $+3,3 \%$ \\
\hline Renault & 3233 & $15,0 \%$ & $(8,1 \%)$ \\
\hline Eramet & 768 & $25,6 \%$ & $+162,4 \%$ \\
\hline Air France-KLM & 428 & $14,3 \%$ & $(44,1 \%)$ \\
\hline CNPAssurances & | 149 & $1,1 \%$ & $(0,8 \%)$ \\
\hline $\begin{array}{l}\text { Dexia } \\
\text { (actions cotées) }\end{array}$ & | 1 & $5,7 \%$ & $(58,8 \%)$ \\
\hline
\end{tabular}

Źródło: jak pod wykresem 1.

Wykres 3. Portfel spółek notowanych na giełdzie zarządzanych przez Agencję ds. Zarządzania Majątkiem w czerwcu 2018 r.

(w mln euro)

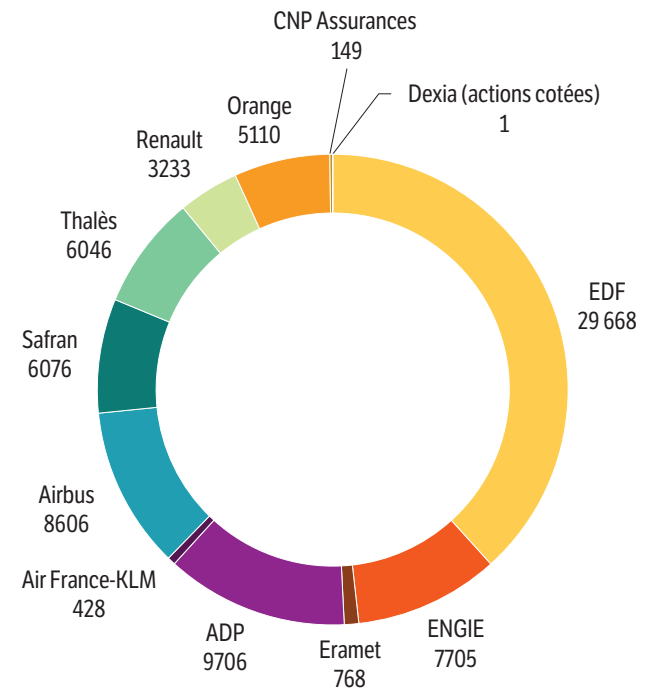

Źródło: jak pod wykresem 1. 
czenia przedsiębiorstw państwowych w gospodarkach, mogą być one mierzone za pomocą różnych wskaźników. We Francji, w porównaniu z pozostałymi państwami wysoko rozwiniętymi, sektor przedsiębiorstw państwowych ma wysoką pozycję w gospodarce, zarówno według wskaźników najczęściej wykorzystywanych w opracowaniach naukowych i badaniach (tj. wprowadzone przez OECD wskaźniki PMR-PO oraz CSS), jak również na podstawie relacji wartości przedsiębiorstw państwowych do PKB. Wskaźnik PMR-PO (Product Market Regulation), który może przyjmować wartość od 0 (najniższy udział własności państwowej) do 6 (największy udział własności państwowej), dla Francji wynosi 3,23, co daje czwartą pozycję wśród państw wysoko rozwiniętych ${ }^{44}$. Drugi ze wskaźników, CSS (Country SOE Share), określający udział własności państwowej wśród dziesięciu największych przedsiębiorstw danego kraju, przyjmujący wartości od 0 (brak własności państwowej) do 100 (całość wartości rynkowej przedsiębiorstw należąca do państwa), został dla Francji określony na 16,7, co stawia Francję na drugim miejscu (po Norwegii) wśród krajów wysoko rozwiniętych ${ }^{45}$. Do podobnych wniosków prowadzi analiza wskaźnika IPE (Index of Public Enterpreneurship), określającego sumę wartości przychodów różnego typu przedsiębiorstw państwowych w odniesieniu do PKB. W roku 2007 wyniósł on dla Francji 5,38 stawiając kraj na czwartej pozycji wśród państw wysoko rozwiniętych ${ }^{46}$.

Duży jest również udział przedsiębiorstw państwowych $\mathrm{w}$ zatrudnieniu w sektorze przedsiębiorstw. Zgodnie z raportem OECD z 2013 r. udział przedsiębiorstw państwowych ogólem (zarówno z większościowymi, jak i mniejszościowymi udziałami państwa) w zatrudnieniu wynosił 9,4\%, co było drugim, po Norwegii, najwyższym wynikiem spośród wszystkich analizowanych państw ${ }^{47}$.

Sprawowanie przez państwo nadzoru właścicielskiego we Francji ma podstawę konstytucyjną. Zgodnie z art. 34 konstytucji tworzenie określonych kategorii zakładów publicznych oraz nacjonalizacja przedsiębiorstw i przenoszenie własności przedsiębiorstw sektora publicznego do sektora prywatnego muszą być dokonywane $\mathrm{w}$ drodze ustawy. W konsekwencji, parlament ma uprawnienie do powoływania $\mathrm{w}$ drodze ustawy podmiotów gospodarczych, będących własnością państwa, podlegających przepisom szczególnym. Ustawa powołująca do życia taki podmiot określa jego misję, sposób finansowania, strukturę rady oraz organy nadzorujące. Parlament może w taki sposób powołać osoby prawne realizujące misję publiczną o charakterze administracyjnym, naukowym, kulturotwórczym, funkcjonujące poza komercyjnymi obszarami gospodarki - EPA (Établissement public à caractère administrative, scentifique, culturel et professionnel) oraz publiczne osoby prawne o charakterze handlowo-przemysłowym - EPIC

$44 \quad$ Ibidem, s. 267, dane za rok 2013.

45 Ibidem.

46 Ibidem, s. 252.

47 Ibidem, s. 256. 
(Établissement public à caractère industriel et commercial), funkcjonujące w obszarach, w których działają również przedsiębiorstwa komercyjne. EPIC wchodzą w zakres pojęciowy przedsiębiorstwa państwowego. Są one tworzone wtedy, gdy państwo uzna, że konkretne usługi nie mogą być świadczone w sposób prawidłowy przez przedsiębiorców prywatnych, ograniczanych regułami konkurencji ${ }^{48}$. Działalność EPIC ma charakter przemysłowy lub handlowy i polega na produkcji i sprzedaży dóbr lub świadczeniu usług. Kierownictwo takich podmiotów jest mianowane przez organy administracji, a kontrola finansowa realizowana jest przez komisarzy rządowych i kontrolerów państwowych ${ }^{49}$. EPIC nie mają kapitału podzielonego na akcje (jego odpowiednikiem są fundusze własne przedsiębiorstwa) i są uprawnione do prowadzenia działalności jedynie w zakresie wskazanym w ustawie lub statucie (misja przedsiębiorstwa). EPIC, w przeciwieństwie do spółek prawa prywatnego, nie podlegają środkom egzekucyjnym i nie mają zdolności upadłościowej. Takimi przedsiębiorstwami, należącymi w całości do państwa, są np. przedsiębiorstwa świadczące usługi transportowe - koleje francuskie (SNFC) oraz spółka transportu miejskiego w Paryżu (RATP).

Prawo francuskie, zgodnie z orzecznictwem Trybunału ds. konfliktów (Tribunal des conflits) ${ }^{50}$, wyróżnia także przedsiębiorstwa państwowe stanowiące połączenie EPA (o charakterze administracyjnym) i EPIC (o charakterze handlowo-przemysłowym). Są to tzw. podmioty publiczne określane mianem przedsiębiorstw o dwóch obliczach (établissement public à double visage) ${ }^{51}$. Misja takich podmiotów obejmuje prowadzenie działalności zarówno na płaszczyźnie administracyjnej, jak i handlowej. Przykładami takich przedsiębiorstw są lotniska Paryża (Aéroports de Paris) i wodne drogi żeglugowe (Voies Navigables de France). Ponadto państwo sprawuje nadzór właścicielski także nad spółkami o mieszanym kapitale, podlegającymi ogólnym przepisom prawa handlowego.

We Francji obowiązuje rekomendowany przez OECD model nadzoru scentralizowanego, charakteryzujący się skoncentrowaniem uprawnień właścicielskich w jednym organie. Organem tym jest utworzona w 2004 r. rządowa Agencja ds. Zarządzania Majątkiem - APE (Agence des Participations de l'État). Powołanie APE było poprzedzone serią raportów, w tym dwóch najważniejszych: raportu Douste-Blazy'ego i raportu Barbier de la Serre'a ${ }^{52}$. Główne rekomendacje zawarte w tych raportach dotyczyły konieczności ujednolicenia statusu korporacyjnego przedsiębiorstw państwowych, ograniczenia członków rad nadzorczych, ustalenia zasad wynagradzania dyrektorów zgodnie ze standardami rynkowymi.

48 F. Grzegorczyk, Przedsiębiorstwo publiczne, op. cit., s. 141.

49 Ibidem, s. 142.

50 Organ władzy sądowniczej składający się z członków Rady Stanu oraz Sądu Kasacyjnego, którego głównym zadaniem jest rozstrzyganie sporów kompetencyjnych pomiędzy sądami powszechnymi a sądami administracyjnymi.

51 F. Grzegorczyk, Przedsiębiorstwo publiczne, op. cit., s. 142.

$52 \quad$ Ibidem, s. 157. 
Zarekomendowano także rozdzielenie podmiotów komercyjnych i podmiotów wykonujących działalność o charakterze misyjnym oraz zwiększenie dostępności spółek akcyjnych o kapitale mieszanym dla inwestorów prywatnych ${ }^{53}$. Postulaty te udało się w dużej mierze zrealizować, ograniczono liczbę członków rad nadzorczych lub rad dyrektorów do 18 osób, wprowadzono rozgraniczenie funkcji właścicielskich państwa i innych zadań aparatu państwowego $0^{54}$. Warto zauważyć, że nadzór scentralizowany dotyczy przede wszystkim przedsiębiorstw publicznych działających w formie organizacyjnej spółki akcyjnej, a nie w formie EPIC.

Agencja APE została utworzona na drodze dekretu numer 2004-963 z dnia 9 września $2004 \mathrm{r}^{55}$. Zgodnie z art. 1 tego dekretu APE podlega ministrowi finansów. Do głównych zadań APE należy zarządzanie portfelem udziałów kapitałowych państwa w największych przedsiębiorstwach. Pracami APE kieruje komisarz ds. udziałów państwowych (Commissaire aux participations de l'Etat), który określa kierunki polityki zarządzania akcjami, biorąc pod uwagę aspekty ekonomiczne i społeczne. APE jest odpowiedzialna za opracowywanie propozycji strategii dla spółek przez nią nadzorowanych oraz monitorowanie sytuacji finansowej i ekonomicznej tych spółek. Agencja APE realizuje cztery cele szczegółowe:

- kontrolę nad spółkami o znaczeniu strategicznym (są to spółki korzystające z ekonomicznego monopolu lub działające w obszarze obronności i bezpieczeństwa),

- zabezpieczenie istnienia silnych podmiotów państwowych,

- wspieranie działalności i konsolidacji przedsiębiorstwa państwowych w sektorach przyczyniających się do wzrostu gospodarczego oraz

- doraźną pomoc finansową przedsiębiorstwom w trudnej sytuacji, których bankructwo mogłoby doprowadzić do powstania ryzyka systemowego ${ }^{56}$.

Portfel udziałów zarządzany przez APE jest bardzo zróżnicowany zarówno pod względem wartości udziału państwa w przedsiębiorstwach, ich formy prawnej, jak również sektorów, w jakich działają. Cztery podstawowe i największe sektory to transport, energetyka, przemysł oraz finanse i usługi, aczkolwiek pod nadzorem APE znajdują się też przedsiębiorstwa z branży lotniczo-kosmicznej, bankowej czy audiowizualnej.

W literaturze przedmiotu francuski model nadzoru właścicielskiego przedstawiany jest jako jeden $\mathrm{z}$ modeli optymalnych ${ }^{57}$.

53 M. Bałtowski, G. Kwiatkowski, Przedsiębiorstwa państwowe, op. cit., s. 106.

54 Ibidem.

55 Décret $n^{\circ 2004-963 ~ d u ~} 9$ septembre 2004 portant création du service à compétence nationale Agence des participations de l'Etat, https://www.legifrance.gouv.fr/affichTexte.do? cidTexte=LEGITEXT000005842300.

56 M. Somai, Ewolucja interwencji państwa, op. cit., s. 61.

57 F. Grzegorczyk, Przedsiębiorstwo publiczne, op. cit., s. 158. 


\section{Hiszpania}

W Hiszpanii Ministerstwo Finansów wydaje corocznie raport na temat przedsiębiorstw państwowych. Ostatni taki raport, „Przedsiębiorstwa i fundacje państwowe. Sprawozdanie ekonomiczno-finansowe 2016" (dalej: EFE) przedstawia stan na dzień 31 grudnia 2016 r. ${ }^{58}$. We wprowadzeniu metodologicznym do raportu przedstawiono klasyfikację rozmaitych podmiotów sektora publicznego. Jak się tam wskazuje, zgodnie z art. 3 ustawy 47/2003 z 26 listopada o prawie budżetowym (dalej: LGP) ${ }^{59}$, znowelizowanej przez ustawę 40/2015 z 1 października o ustroju prawnym sektora publicznego (dalej: LRJSP $)^{60}$, sektor publiczny (sector público) dzieli się na trzy podsektory: sektor publiczny administracyjny (sector público administrativo), sektor przedsiębiorstw publicznych (sector público empresarial) i sektor fundacji publicznych (sector público fundacional).

Sektor przedsiębiorstw publicznych obejmuje:

- przedsiębiorstwa - jednostki publiczne (entidades públicas empresariales),

- państwowe spółki handlowe (sociedades mercantiles estatales),

- wszelkie instytucje i jednostki (organismos y entidades) prawa publicznego związane lub zależne od administracji ogólnej państwa (Administración General del Estado), konsorcja (consorcios) i fundusze (fondos) niemające osobowości prawnej i niewłączone do sektora publicznego administracyjnego (LGP, art. 3.2).

Do przedsiębiorstw - jednostek publicznych odnosi się artykuł 166.1 lit. a ustawy 33/2003 z 3 listopada o majątku administracji publicznych (dalej: LPAP) $)^{61}$, oraz artykuły od 103 do 108 LRJSP. Ich definicja znajduje się w artykule 103 LRJSP:

1. Przedsiębiorstwami - jednostkami publicznymi sa jednostki prawa publicznego z własna osobowościa prawną, majątkiem i autonomia w zarządzaniu, które

58 Empresas y Fundaciones Estatales. Informe económico-financiero 2016, Ministerio de Hacienda y Función Pública, s. a., http://www.igae.pap.hacienda.gob.es/sitios/ igae/es-ES/Contabilidad/InformacionEconomica/SiteAssets/Paginas/iaempresasinforme/Empresas\%20y\%20Fundaciones\%20\%20Estatales.\%20Informe\%20 econ\%C3\%B3mico-financiero\%202016.pdf. Wcześniejsze raporty nosiły krótszy tytuł Empresas Estatales. Informe económico-financiero [...], niemniej obejmowały także fundacje. Właściwym ministerstwem było poprzednio Ministerio de Hacienda y Administraciones Públicas, a jeszcze wcześniej Ministerio de Hacienda.

59 Ley 47/2003, de 26 de noviembre, General Presupuestaria, BOE, https://www.boe.es/ buscar/act.php?id=BOE-A-2003-21614\&tn=1\&p=20151030\&acc=Elegir （wersja ujednolicona, wg stanu na koniec 2016 r.).

60 Ley 40/2015, de 1 de octubre, de Régimen Jurídico del Sector Público, BOE, https://www. boe.es/buscar/doc.php?id=BOE-A-2015-10566.

${ }_{61}$ Ley 33/2003, de 3 de noviembre, del Patrimonio de las Administraciones Públicas, BOE, https://www.boe.es/buscar/act.php?id=BOE-A-2003-20254\&tn=1\&p=20151031 (wersja ujednolicona, wg stanu na koniec 2016 r.). 
finansowane sa głównie $z$ dochodów $z$ rynku $i$ które obok sprawowania władzy administracyjnej prowadza działalność o charakterze świadczeń [actividades prestacionales], zarządzania ustugami lub produkcją odpłatnych dóbr [susceptibles de contraprestación] $w$ interesie publicznym. 2. Przedsiębiorstwa - jednostki publiczne zależa od administracji ogólnej Państwa lub od zwiąanego z nia lub zależnego od niej ciała autonomicznego, do którego należy kierownictwo strategiczne, ocena wyników działalności i kontrola skuteczności tychże. 3. Niezależnie od nazwy, jeśli instytucja publiczna [organismo público] ma charakter prawny przedsiębiorstwa - jednostki publicznej, w jej nazwie musi zawierać się wskazanie "przedsiębiorstwo - jednostka publiczna” lub jego skrót „E. P. E”.

Państwowe spółki handlowe zdefiniowane są w artykule 166.1 lit. c LPAP i artykule 111 LRJSP. Państwową spółką handlową jest spółka handlowa, nad którą państwo sprawuje kontrolę:

- albo przez to, że bezpośredni udział administracji generalnej państwa lub jednostek składających się na państwowy instytucjonalny sektor publiczny, w tym państwowych spółek handlowych, w kapitale założycielskim spółki wynosi ponad $50 \%$,

- albo przez to, że administracja generalna państwa lub jednostki publiczne związane z nią lub jej podległe dysponują większością głosów w spółce handlowej będącej spółką giełdową, mają prawo powoływać i odwoływać większość członków jej organu zarządzającego lub ich przedstawiciele stanowią większość członków jej rady.

Państwowe spółki handlowe muszą posiadać w swojej nazwie wskazanie „państwowa spółka publiczna” lub jego skrót „S. M. E.”.

Artykuł 166.1 lit b LPAP wspomina o jednostkach prawa publicznego związanych $\mathrm{z}$ administracją generalną państwa lub jej instytucjami publicznymi, których dochody pochodzą przynajmniej w 50\% z operacji rynkowych. Do przedsiębiorstw tych stosuje się ogólny schemat rachunkowości przedsiębiorstw hiszpańskich.

Konsorcja posiadające własną osobowość prawną uwzględnione są w klasyfikacji publicznego sektora państwowego przedstawionej w artykule 2.2 lit c LGP. Artykuł 118 LRJSP definiuje konsorcja jako: jednostki prawa publicznego $z$ własna, wyróżniona osobowościa prawna, stworzone przez administracje publiczne lub jednostki wchodzace $w$ skład instytucjonalnego sektora publicznego, $z$ ewentualnym udziałem jednostek prywatnych, $w$ celu prowadzenia działalności leżącej $w$ interesie powszechnym $i$ w ramach ich kompetencji. $\mathrm{W}$ nazwie konsorcjów musi figurować wskazanie „konsorcjum” lub, jako jego skrót, litera „C”. Statut każdego konsorcjum - jak przewiduje artykuł 120 LRJSP - określany jest przez administrację publiczną, do którego jest ono przypisane.

Fundusze państwowego sektora publicznego niemające osobowości prawnej wymienione są w artykule 2.2 lit. f LGP. Na mocy artykułów 137 i 139 LRJSP 
fundusze takie tworzone są w drodze ustawy, która określa sposób przypisania funduszu do administracji generalnej państwa. Fundusze takie muszą w nazwie nosić wskazanie „fundusz nieposiadający osobowości prawnej” lub jego skrót „F. C. P. J”.

Fundacjami publicznego sektora państwowego są, zgodnie z artykułem 128.1 LRJSP, fundacje, które: a) zostały pierwotnie założone z wykorzystaniem bezpośredniego lub pośredniego większościowego wkładu administracji generalnej państwa lub wkład taki otrzymały później, lub b) majątek fundacji składa się $\mathrm{w}$ ponad $50 \% \mathrm{z}$ dóbr lub praw wniesionych lub scedowanych przez podmioty państwowego instytucjonalnego sektora publicznego w sposób trwały, lub c) większość głosów w radzie fundacji mają przedstawiciele państwowego instytucjonalnego sektora publicznego.

Zgodnie ze stanem na 31 grudnia 2016 r. liczba podmiotów państwowego sektora publicznego przedsiębiorstw i fundacji wynosiła 244, z czego 207 podmiotów należało do sektora przedsiębiorstw państwowych, a 37 do sektora fundacji publicznych. Wśród 207 podmiotów sektora publicznych przedsiębiorstw państwowych 13 stanowiło przedsiębiorstwa - jednostki publiczne, 153 - państwowe spółki handlowe, a 41 - inne instytucje i jednostki prawa publicznego związane z administracją generalną państwa lub od niej zależne (EFE, s. 24, 29).

Wskazane 207 przedsiębiorstw publicznych rozdystrybuowane było pod względem przyporządkowania między siedem resortów ${ }^{62}$ :

- Gospodarka i Konkurencyjność - 15,

- Finanse i Administracja Publiczna - 114,

- Infrastruktura - 72,

- Przemysł, Energia i Turystyka - 3,

- Obronność - 1,

- Edukacja, Kultura i Sport - 1,

- Rolnictwo, Żywność i Środowisko - 1 .

W raporcie EFE i na stronach internetowych Ministerstwa Finansów nie ma praktycznie żadnych informacji o sposobie sprawowania nadzoru właścicielskiego nad przedsiębiorstwami państwowymi.

Jak wskazuje się w literaturze przedmiotu, Hiszpania należy do państw, w których obowiązuje scentralizowany model nadzoru nad sektorem przedsiębiorstw państwowych ${ }^{63}$. Wynika to przede wszystkim z ustawy o prawie budżetowym:

62 EFE, s. 72. W raporcie używa się terminu „przypisanie” (adscripción, s. 72-73). Zaznacza się przy tym w części wstępnej, że przypisanie nie we wszystkich przypadkach pokrywa się z zależnością (dependencia). Przypadków takich jest, jak wynika z przedstawionych danych, jedenaście. „Przypisanie” oznacza, że ministerstwo pełni w stosunku do przedsiębiorstwa rolę regulacyjną, ,zależność” zaś odnosi się do ministerstwa, które wniosło do przedsiębiorstwa udziały. Zob. EFE, s. 31.

63 M. Bałtowski, G. Kwiatkowski, Przedsiębiorstwa państwowe, op. cit., s. 75. 
Administrowanie prawami finansów publicznych przynależy do Ministerstwa Finansów i instytucji autonomicznych, zgodnie z posiadanymi przez nie tytułami, bez uszczerbku dla kompetencji, które niniejsza ustawa lub inne ustawy przyznaja innym departamentom lub jednostkom państwowego sektora publicznego (art. 6.1 LGP) ${ }^{64}$.

Według danych OECD za rok 2012 wartość udziałów państwa w przedsiębiorstwach w odniesieniu do PKB wyniosła zaledwie 0,9\% (w Finlandii aż 44,8\%, Polsce - 22,1\%, w Niemczech - 3,8\%) ${ }^{65}$.

\section{Litwa}

Na koniec czerwca 2018 r. na Litwie działało 65 przedsiębiorstw państwowych ${ }^{66}$, w większości w sektorach energii, transportu, komunikacji i leśnictwa. Nadzór nad nimi ma charakter zdecentralizowany, jest 15 instytucji (głównie ministerstwa), które wykonują prawa i obowiązki państwa jako właściciela ${ }^{67}$. Ponadto w 2012 r. utworzono Centrum Koordynacji Zarządzania (Valdymo koordinavimo centras) - instytucję analityczną, której zadaniem było zapewnienie spójnego i profesjonalnego zarządzania przedsiębiorstwami państwowymi.

Model nadzoru właścicielskiego nad przedsiębiorstwami państwowymi na Litwie podlegał $\mathrm{w}$ ostatnich latach zmianom m.in. w związku z koniecznością wdrożenia zaleceń OECD dla Litwy, jako państwa przystępującego (Litwa została członkiem OECD 5 lipca 2018 r.). Rekomendacje OECD wskazywały m.in. na konieczność:

- wzmocnienia statusu Centrum Koordynacji Zarządzania,

- zwiększenia niezależności zarządów i rad nadzorczych, m.in. poprzez zapewnienie przejrzystych i wystandaryzowanych kryteriów wyboru,

- przeglądu form prawnych przedsiębiorstw państwowych,

- wprowadzenia obowiązku przestrzegania tzw. wytycznych w sprawie przejrzystości, przynajmniej dla największych przedsiębiorstw.

Na Litwie istnieją trzy formy prawne dla przedsiębiorstw państwowych.

64 BOE, https://www.boe.es/buscar/doc.php?id=BOE-A-2003-21614.

65 M. Bałtowski, G. Kwiatkowski, Przedsiębiorstwa państwowe, op. cit., s. 255.

${ }_{66}$ Przedsiębiorstwo państwowe definiowane jako podmiot gospodarczy, nad którym państwo sprawuje kontrolę korporacyjną i który znaczną część przychodów uzyskuje ze sprzedaży dóbr i usług o charakterze rynkowym. Definicja za: M. Bałtowski, G. Kwiatkowski, Przedsiębiorstwa państwowe, op. cit.

${ }^{67}$ Informacje na podstawie danych ze strony internetowej Centrum Koordynacji Zarządzania, https://vkc.sipa.lt/en/apie-imones/vvi-portfelio-informacija/\#1543476938 028-318f4fe3-e823. 


\section{Pierwsza forma prawna}

W rozumieniu ustawy o przedsiębiorstwach państwowych i komunalnych ${ }^{68}$ są to przedsiębiorstwa państwowe (valstybès įmonè, VI ). Celem przedsiębiorstwa państwowego i przedsiębiorstwa komunalnego jest świadczenie usług publicznych, wytwarzanie produktów i wykonywanie innych czynności w celu zaspokojenia interesu publicznego. Przedsiębiorstwo państwowe powstaje na mocy uchwały rządu (art. 5 ustawy o przedsiębiorstwach państwowych i komunalnych). Zgodnie $\mathrm{z}$ art. 4 ust. 1 ustawy przedsiębiorstwo państwowe jest własnością państwa, które wykonuje prawa i obowiązki właściciela za pośrednictwem jednej instytucji upoważnionej przez rząd. Organami przedsiębiorstwa są instytucja rządowa, która wykonuje prawa i obowiązki państwa jako właściciela, oraz kierownik przedsiębiorstwa (art. 9 ustawy o przedsiębiorstwach państwowych i komunalnych). Statut przedsiębiorstwa może ponadto przewidywać utworzenie kolegialnego organu zarządzającego - zarządu, złożonego z urzędników służby cywilnej, przedstawicieli pracowników oraz innych osób fizycznych.

Instytucja rządowa, która wykonuje prawa i obowiązki państwa jako właściciela (art. 4 ust. 4 ustawy o przedsiębiorstwach państwowych i komunalnych), m.in.:

- zatwierdza strategię działania przedsiębiorstwa,

- zatwierdza statut przedsiębiorstwa,

- podejmuje decyzję o zmianie siedziby spółki,

- powołuje i odwołuje kierownika spółki, ustala warunki jego umowy o pracę, zawiera i wypowiada taką umowę, zatwierdza regulamin stanowiska kierownika spółki,

- powołuje i odwołuje członków zarządu, gdy ten został powołany,

- określa wymagania dla członków zarządu,

- zatwierdza roczne sprawozdanie finansowe oraz podział zysku (straty),

- wybiera biegłego rewidenta,

- podejmuje decyzję o reorganizacji, restrukturyzacji lub likwidacji przedsiębiorstwa,

- powołuje i odwołuje likwidatora spółki.

Zgodnie z art. 16 ustawy o przedsiębiorstwach państwowych i komunalnych co roku kierownik przedsiębiorstwa przedkłada zarządowi i instytucji rządowej, która wykonuje prawa i obowiązki państwa jako właściciela, sprawozdanie z działalności przedsiębiorstwa razem ze sprawozdaniem finansowym. Sprawozdanie $\mathrm{z}$ działalności obejmuje informacje na temat m.in. wdrażania strategii działania przedsiębiorstwa, inwestycji i transakcji, planów działań i prognoz, głównych czynników ryzyka i sposobów ich zminimalizowania, wewnętrznego

68 Lietuvos Respublikos valstybès ir savivaldybès įmoniu istatymas, I-722, Valstybės žinios, 1994-12-31, Nr. 102-2049, ze zm. 
sytemu kontroli, zmianach w wartości aktywów przedsiębiorstwa, działalności przedstawicielstw i oddziałów, zmian w liczbie pracowników.

\section{Druga i trzecia forma prawna}

Dwie pozostałe formy prawne przedsiębiorstw państwowych na Litwie to spółki z ograniczoną odpowiedzialnością - UAB (uždaroji akcinė bendrovè) oraz spółki akcyjne - AB (akcine bendrové), tworzone na ogólnych zasadach zgodnie z ustawą o spółkach ${ }^{69}$, w których akcje będące własnością państwa zapewniają więcej niż 1/2 głosów na walnym zgromadzeniu akcjonariuszy (art. 2 ust. 15 ustawy o zarządzaniu i rozporządzaniu mieniem państwowym i komunalnym oraz jego wykorzystaniu ${ }^{70}$ ).

Zgodnie $\mathrm{z}$ art. 7 ustawy o zarządzaniu i rozporządzaniu mieniem państwowym i komunalnym oraz jego wykorzystaniu funkcje właściciela własności państwowej są realizowane przez Seimas Republiki Litewskiej oraz rząd. Artykuł 23 ustawy o zarządzaniu i rozporządzaniu mieniem państwowym i komunalnym oraz jego wykorzystaniu reguluje sposób wykonywania praw i obowiązków państwa jako właściciela przedsiębiorstw państwowych, w rozumieniu ustawy o przedsiębiorstwach państwowych i komunalnych, oraz udziałów i akcji w spółkach z ograniczoną odpowiedzialnością i spółkach akcyjnych. Ponadto na podstawie tego artykułu rząd przyjął rozporządzenia określające szczegółowe zasady nadzoru właścicielskiego, w tym przede wszystkim:

- rozporządzenie rządu nr 665 w sprawie zatwierdzenia procedury wykonywania praw państwa w przedsiębiorstwach państwowych ${ }^{71}$, tzw. wytyczne w sprawie nadzoru właścicielskiego,

- rozporządzenie rządu nr 1052 w sprawie zatwierdzenia wytycznych dotyczących zapewnienia przejrzystości działalności przedsiębiorstw państwowych ${ }^{72}$, tzw. wytyczne w sprawie przejrzystości,

- rozporządzenie rządu nr 631 w sprawie zatwierdzenia procedury wyboru kandydatów do organów kolegialnych przedsiębiorstw państwowych ${ }^{73}$, tzw. wytyczne w sprawie nominacji.

69 Lietuvos Respublikos akcinių bendroviu istatymas, VIII-1835, Valstybès žinios, 200007-31, Nr. 64-1914, ze zm.

70 Lietuvos Respublikos valstybès ir savivaldybiu turto valdymo, naudojimo ir disponavimo juo įstatymas, VIII-729, Valstybės žinios, 1998-06-12, Nr. 54-1492, ze zm.

71 Lietuvos Respublikos vyriausybe nutarimas dèl valstybès turtiniu ir neturtiniu teisiu igyvendinimo valstybès valdomose įmonèse tvarkos aprašo patvirtinimo, 665, Valstybès žinios, 2012-06-16, Nr. 67-3394, ze zm.

72 Lietuvos Respublikos vyriausybè nutarimas dèl valstybès valdomu i̇moniu veiklos skaidrumo užtikrinimo gairių aprašo patvirtinimo, 1052, Valstybès žinios, 2010-07-24, Nr. 88-4637, ze zm.

73 Lietuvos Respublikos vyriausybe nutarimas dèl kandidatu $\dot{i}$ valstybès imonès ar savivaldybès įmones valdyba ir kandidatu $i$ valstybés ar savivaldybés valdomos 
Wykonywanie praw i obowiązków państwa w zakresie nadzoru właścicielskiego powierzone zostało instytucjom wskazanym przez rząd - głównie ministerstwom ${ }^{74}$, które wyznaczają urzędników odpowiedzialnych za nadzór nad poszczególnym przedsiębiorstwami państwowymi.

Równocześnie w Ministerstwie Gospodarki wyodrębniona została agencja monitorująca i prognozująca (Stebésenos ir Prognozių Agentūra), pod nazwą Centrum Koordynacji Zarządzania, którego zadaniem jest monitorowanie i dokonywanie analiz w zakresie zarzadzania przedsiębiorstwami państwowymi. Zadania Centrum obejmują m.in. ${ }^{75}$ :

- pozyskiwanie od instytucji, które wykonują prawa i obowiązki państwa jako właściciela/udziałowca/akcjonariusza, informacji na temat działalności przedsiębiorstw państwowych oraz ich wyników, a także decyzji związanych z nadzorem nad nimi oraz analiza tych informacji pod kątem ich zgodności m.in. z wymogami w zakresie zarządzania i przejrzystości,

- publikowanie rocznych i okresowych raportów na temat przedsiębiorstw państwowych i ich działalności,

- dokonywanie przeglądu projektów strategii działalności przedsiębiorstw państwowych, formułowanie zaleceń dla instytucji, które wykonują prawa i obowiązki państwa jako właściciela/udziałowca/akcjonariusza w zakresie celów określonych w strategiach oraz określania wskaźników ich oceny,

- doradzanie instytucjom, które wykonują prawa i obowiązki państwa jako właściciela/udziałowca/akcjonariusza, w zakresie efektywnego zarządzania przedsiębiorstwami państwowymi, realizacji ich strategii oraz celów,

- ocena wyników rentowności przedsiębiorstw państwowych oraz dostarczanie informacji o planowanych dywidendach i wypłatach zysków przedsiębiorstw państwowych,

- publikowanie informacji na temat wyboru członków organów kolegialnych przedsiębiorstw państwowych.

Główne zasady nadzoru właścicielskiego, określone w rozporządzeniach rządu, obejmują m.in. wytyczne w sprawie nadzoru właścicielskiego, wytyczne w sprawie przejrzystości oraz wytyczne w sprawie nominacji:

bendroves visuotinio akcininku susirinkimo renkama kolegialu priežiūros ar valdymo organą atrankos aprašo patvirtinimo, 631, TAR, 2015-06-23, Nr. 10088, ze zm.

74 Informacje na temat litewskich przedsiębiorstw państwowych i ministerstwach sprawujących nad nimi nadzór można znaleźć na stronie internetowej Centrum Koordynacji Zarządzania, https://vkc.sipa.lt/en/apie-imones/vvi-sarasas/.

75 Strona internetowa Centrum Koordynacji Zarządzania: https://vkc.sipa.lt/en/valdysena-lietuvoje/\#institucine-sistema. 


\section{Wytyczne w sprawie nadzoru właścicielskiego}

- określenie głównych celów przedsiębiorstw państwowych w postaci wymogu osiągnięcia wyznaczonego wskaźnika rentowności, zapisanego w rozporządzeniu rządu ${ }^{76}$ oraz poprzez wskazanie oczekiwań rządu i głównych wytycznych w zakresie realizacji szczególnych obowiązków ${ }^{77}$, sformułowanych w tzw. liście o oczekiwaniach państwa, przedkładanym każdemu przedsiębiorstwu państwowemu,

- podział przedsiębiorstw państwowych na trzy grupy, w zależności od przypisanego im celu ${ }^{78}$ :

- grupa 1A - działalność rynkowa; zwiększanie wartości i maksymalizacja zysku, np. przedsiębiorstwo Vİ Visagino energija czy spółka UAB Toksika,

- grupa 1B - działalność rynkowa; zwiększanie wartości i realizacja celów społecznych i politycznych, np. największe spółki sektora energii, transportu i komunikacji, jak grupa Lietuvos Energija czy spółka AB Lietuvos geležinkeliai,

- grupa 2 - realizacja celów społecznych i politycznych oraz działalność nierynkowa, np. przedsiębiorstwa Vİ Lietuvos naftos produktų agentura czy VI Oro navigacija,

- zobowiązanie przedsiębiorstw państwowych do opracowania strategii działalności co 3 lata (co 4 lata w przypadku przedsiębiorstw państwowych w rozumieniu ustawy o przedsiębiorstwach państwowych i komunalnych) oraz ich corocznej aktualizacji,

- rozdzielenie funkcji nadzoru właścicielskiego od funkcji regulacyjnej w ministerstwach wykonujących prawa i obowiązki państwa w zakresie nadzoru właścicielskiego,

- zobowiązanie przedsiębiorstw państwowych ważnych z punktu widzenia interesu publicznego oraz o strategicznym znaczeniu dla bezpieczeństwa narodowego do posiadania kolegialnych organów zarządczych oraz komitetów m.in. ds. kontroli wewnętrznej i wynagrodzeń,

76 Zob. np. Lietuvos Respublikos Vyriausybè nutarimas Dél valstybès valdomu įmoniu siektinu pelningumo rodikliu 2019-2021 metams nustatymo, 12, TAR, 2019-01-14, Nr. 500, ze zm.

77 Szczególne obowiązki to zobowiązanie przedsiębiorstwa państwowego do pełnienia funkcji zdefiniowanych w ustawie lub rozporządzeniach rządu, które spełniają jedno z kryteriów, np. alokacji środków budżetowych na pełnienie funkcji lub finansowanie tych funkcji z funduszy UE lub innych funduszy, czyli rekompensaty za szczególne obowiązki. Przypisanie przedsiębiorstwu państwowemu szczególnych obowiązków musi zostać zatwierdzone przez Centrum Koordynacji Zarządzania; State-Owned Enterprises in Lithuania, Annual Report 2017, Stebėsenos ir Prognozių Agentūra, 2018, https://vkc.sipa.lt/wp-content/uploads/2018/09/SOE_Report_2018_EN_WEB.pdf.

78 State-Owned Enterprises in Lithuania, Annual Report 2017, Stebesenos ir Prognozių Agentūra, 2018, https://vkc.sipa.lt/wp-content/uploads/2018/09/SOE_Report_2018_ EN_WEB.pdf. 
- określenie zasad ustalania wysokości wynagrodzenia dla członków organów kolegialnych przedsiębiorstw państwowych.

\section{Wytyczne w sprawie przejrzystości}

- wyznaczenie Ministerstwa Gospodarki jako odpowiedzialnego za formułowanie i koordynowanie polityki w zakresie nadzoru właścicielskiego nad przedsiębiorstwami państwowymi,

- zobowiązanie przedsiębiorstw państwowych do ujawniania informacji o ich działalności, w tym o szczególnych obowiązkach,

- zobowiązanie przedsiębiorstw państwowych do stosowania międzynarodowych standardów rachunkowości,

- zobowiązanie Centrum Koordynacji Zarządzania do opracowywania raportów zbiorczych na temat przedsiębiorstw państwowych i ich działalności.

\section{Wytyczne w sprawie nominacji}

- określenie składu organów kolegialnych i nadzorczych przedsiębiorstw państwowych, w tym wielkości udziału członków niezależnych,

- określenie wymogów dla kandydatów na członków organów kolegialnych i nadzorczych przedsiębiorstw państwowych,

- określenie procedury wyboru członków organów kolegialnych i nadzorczych przedsiębiorstw państwowych.

Odrębne przepisy określają kwestie nadzoru właścicielskiego w odniesieniu do przedsiębiorstw państwowych o strategicznym znaczeniu dla bezpieczeństwa narodowego. W art. 6 ustawy o obiektach ważnych dla zapewnienia bezpieczeństwa narodowego ${ }^{79}$ jako sektory o znaczeniu strategicznym dla bezpieczeństwa narodowego wymieniono energię, transport, technologie informatyczne, telekomunikacje i inne zaawansowane technologie, finanse i działalność kredytową oraz sprzęt wojskowy.

W ustawie określono trzy kategorie przedsiębiorstw:

- kategoria I - przedsiębiorstwa państwowe lub komunalne w rozumieniu ustawy o przedsiębiorstwach państwowych i komunalnych lub spółki, w których państwo ma 100\% udziałów/akcji,

- kategoria II - spółki, w których państwo ma co najmniej 2/3 udziałów/akcji, - kategoria III - spółki, w których państwo ma mniej niż $2 / 3$ udziałów/akcji oraz załączono listy przedsiębiorstw objętych każdą z tych kategorii.

79 Lietuvos respublikos nacionaliniam saugumui užtikrinti svarbiu objektu apsaugos istatymas, IX-1132, Valstybės žinios, 2002-10-30, Nr. 103-4604, ze zm. Ustawa dostępna w języku angielskim: https://e-seimas.lrs.lt/portal/legalAct/lt/TAD/a7ba7f402 11411 e88a05839ea3846d8e?jfwid=-1d1yg0jya3. 
Dla każdej z kategorii określono odrębne zasady dla zatwierdzania przez parlament Litwy, rząd lub Komisję ds. koordynacji ochrony obiektów ważnych dla zapewnienia bezpieczeństwa narodowego (art. 19 ustawy o obiektach ważnych dla zapewnienia bezpieczeństwa narodowego), powoływaną przez rząd ${ }^{80}$, decyzji mogących skutkować zmniejszeniem udziału państwa w przedsiębiorstwach (np. w przypadku reorganizacji, przekształcenia, restrukturyzacji lub likwidacji). Ponadto dla poszczególnych kategorii przewidziano ograniczenia w zakresie inwestowania, umożliwiając nabycie udziałów/akcji inwestorom spełniającym kryteria zgodności z narodowym interesem w zakresie bezpieczeństwa, określone w art. 11 ustawy o obiektach ważnych dla zapewnienia bezpieczeństwa narodowego. Ustawa o obiektach ważnych dla zapewnienia bezpieczeństwa narodowego reguluje również szczegółową procedurę weryfikacji spełnienia kryteriów zgodności z narodowym interesem $\mathrm{w}$ zakresie bezpieczeństwa $\mathrm{w}$ stosunku do inwestorów (art. 12 ustawy) oraz transakcji (art. 13 ustawy). Ponadto w ustawie o obiektach ważnych dla zapewnienia bezpieczeństwa narodowego przewidziano, że przedsiębiorstwa o znaczeniu dla bezpieczeństwa narodowego muszą przygotowywać plany bezpieczeństwa, obejmujące środki m.in. z zakresu cyberbezpieczeństwa oraz poufności informacji (art. 15 ustawy).

\section{Łotwa}

Według danych OECD we wrześniu 2015 r. na Łotwie działało 67 przedsiębiorstw państwowych, których wyłącznym właścicielem było państwo, 5 przedsiębiorstw, w których państwo miało powyżej 50\% udziałów, oraz 11 przedsiębiorstw, w których posiadało od 10 do $50 \%$ udziałów $^{81}$. Największe z nich to Citadele Bank, Lattelecom (usługi komunikacyjne), Latvijas valsts meži (lasy państwowe), Latvenergo (sektor energetyczny) oraz łotewskie koleje Latvijas dzelzcel̦š.

Nadzór nad przedsiębiorstwami państwowymi na Łotwie ma charakter zdecentralizowany, z 13 instytucjami (w tym 11 ministerstwami, jedną instytucją publiczną - Narodową Radą ds. Mediów Elektronicznych oraz Agencją ds. Prywatyzacji, która jest przedsiębiorstwem państwowym), które wykonują prawa i obowiązki państwa jako właściciela, oraz powołaną w 2015 r. instytucją koordynującą (Międzyresortowe Centrum Koordynacji, Pārresoru koordinācijas centrs, Cross-Sectoral Coordination Centre, CSCC).

80 Investment policy related to National Security. Notification by Lithuania, OECD, 23 October 2018, http://www.oecd.org/officialdocuments/publicdisplaydocumentpdf/?cote $=\mathrm{DAF} / \mathrm{INV} / \mathrm{RD}(2018) 6 \&$ docLanguage $=\mathrm{En}$.

81 Dane za: Corporate Governance in Latvia, OECD 2017, s. 44, https://read.oecd-ilibrary.org/governance/corporate-governance-in-latvia_9789264268180-en\#page46. 
Model nadzoru właścicielskiego nad przedsiębiorstwami państwowymi podlegał w ostatnich latach istotnym zmianom. Wynikało to przede wszystkim z tego, że w maju 2013 r. Łotwa rozpoczęła przygotowania do przystąpienia do OECD. Jednym $z$ elementów tego procesu było przyjęcie przez ten kraj podstawowych instrumentów zalecanych przez OECD w zakresie nadzoru korporacyjnego (corporate governance). W ramach reform na Łotwie wprowadzono instytucję koordynującą, której funkcje pełni wspomniane Międzyresortowe Centrum Koordynacji, a także przyjęto nową ustawę dotyczącą nadzoru korporacyjnego. W dużych łotewskich przedsiębiorstwach zaczęto przywracać zarządy, zlikwidowane w 2009 r. Łotwa została członkiem OECD 1 lipca 2016 r. (z raportu OECD z 2017 r. ${ }^{82}$ wynika, że rynek kapitałowy w tym kraju jest niewielki, więc dalsza poprawa zarządzania przedsiębiorstwami może doprowadzić do jego wzrostu dzięki przyciągnięciu inwestorów).

$\mathrm{Na}$ Łotwie istnieją dwie podstawowe formy prawne przedsiębiorstw państwowych: spółki z ograniczoną odpowiedzialnością (sabiedrība ar ierobežotu atbildību) oraz spółki akcyjne (akciju sabiedrība). Ponadto istnieje jeden podmiot o odrębnym charakterze - narodowa instytucja finansowa Altum ${ }^{83}$ (attīstības finanšu institūcija) powołana na mocy ustawy o instytucji ds. finansowania rozwo$\mathrm{ju}^{84}$, która weszła w życie 1 marca $2015 \mathrm{r}^{85}$.

Warunki, które muszą zostać spełnione, aby państwo mogło nabyć lub utrzymać udziały w spółkach, określono w art. 88 ust. 1 ustawy o strukturze administracyjnej państwa ${ }^{86}$. Zgodnie z jej postanowieniami państwo może założyć spółkę kapitałową lub nabyć udział w istniejącej spółce kapitałowej w celu skutecznego wykonywania swoich funkcji pod warunkiem spełnienia jednego z następujących kryteriów:

- zapobieganie nieprawidłowościom w funkcjonowaniu rynku - sytuacja, w której rynek nie jest w stanie zaspokoić interesu publicznego w danej dziedzinie,

- działalność spółki kapitałowej, której właścicielem jest państwo, lub spółki kapitałowej kontrolowanej przez państwo ma na celu wytworzenie towarów lub usług o strategicznym znaczeniu dla rozwoju obszaru administracyjnego państwa, dla samorządu lokalnego lub bezpieczeństwa państwa,

- zarządzanie nieruchomościami o strategicznym znaczeniu dla rozwoju obszaru administracyjnego państwa, samorządu lokalnego lub bezpieczeństwa państwa.

82 Corporate Governance in Latvia, op. cit., s. 11, https://read.oecd-ilibrary.org/governance/corporate-governance-in-latvia_9789264268180-en\#page11.

83 Informacja w jęz. angielskim: https://www.altum.lv/en/.

84 Ustawa z 30 października 2014 - Attīstības finanšu institūcijas likums.

85 Corporate Governance in Latvia, op. cit., s. 44.

86 Valsts pārvaldes iekārtas likums (State Administration Structure Law, dostępne w jęz. angielskim na: https://likumi.lv/ta/en/en/id/63545). 
Zgodnie z art. 87 ust. 2 ustawy o strukturze administracyjnej państwa, co do zasady, do działalności państwa w obszarze prawa prywatnego będą stosowane ogólne przepisy prawa (o ile w ustawach lub rozporządzeniach nie przewidziano inaczej). W szczególności znajdą zastosowanie przepisy prawa handlowego z 14 kwietnia $2000 \mathrm{r}^{87}$, ustawy o grupach kapitałowych z 23 marca $2000 \mathrm{r}^{88}$ oraz ustawy o rynku instrumentów finansowych z 20 listopada $2003 \mathrm{r}^{89}$.

Prawa i obowiązki rządu jako instytucji nadzorującej określono w ustawie z 16 października 2014 r. w sprawie zarządzania udziałami kapitałowymi państwa i spółkami kapitałowymi (ustawa PPCSCL) ${ }^{90}$, która weszła w życie 1 stycznia 2015 r. W ustawie tej określono tryb powoływania, reorganizacji, sprzedaży i likwidacji spółek z udziałem państwa oraz zwiększenia lub zmniejszenia tych udziałów. Zawiera ona także postanowienia dotyczące zarządzania spółkami, których wyłącznym właścicielem jest państwo, i spółkami, w których posiada ono udziały, sposobu określenia podziału zysku i wypłaty dywidend, jak również wynagrodzeń członków organów spółek.

Wykonywanie praw i obowiązków państwa w zakresie nadzoru właścicielskiego powierzono ministerstwom według ich zakresu branżowego. Ich działalność koordynuje - utworzone na podstawie art. 22 ustawy PPCSCL (zarządzenie Rady Ministrów nr 273 z 2015 r.91) -Międzyresortowe Centrum Koordynacji, działające od 1 czerwca 2015 r. Zadania Międzyresortowego Centrum Koordynacji obejmują m.in.:

- opracowanie wytycznych i projektów rozporządzeń dotyczących zarządzania przedsiębiorstwami państwowymi,

- ocenę projektów strategii operacyjnych i sprawozdań rocznych przedkładanych przez przedsiębiorstwa państwowe i nadzorujące je instytucje,

- wydawanie opinii na temat spełnienia warunków, aby państwo mogło nabyć lub utrzymać udziały w spółkach,

- zapewnianie doradztwa premierowi, radzie ministrów, ministerstwom, osobom zarządzającym i odpowiedzialnym pracownikom, a także organizację szkoleń dotyczących zarządzania przedsiębiorstwami państwowymi,

87 Komerclikums (The Commercial Law), dostępne w jęz. angielskim na: https://likumi. $\mathrm{lv} / \mathrm{ta} / \mathrm{en} / \mathrm{en} / \mathrm{id} / 5490$.

${ }^{88}$ Koncernu likums (Group of Companies Law), dostępne w jęz. angielskim na: https:// likumi.lv/ta/en/en/id/4423.

89 Finanšu instrumentu tirgus likums (Financial Instrument Market Law), dostępne w jęz. angielskim na: https://likumi.lv/ta/en/en/id/81995.

90 Publiskas personas kapitāla dậu un kapitālsabiedrību pārvaldības likums (Law on Governance of Capital Shares of a Public Person and Capital Companies [PPCSCL]), dostępne w jęz. angielskim na: http://www.vvc.gov.lv/export/sites/default/docs/LRTA/Likumi/ Governance_of_Capital_Shares_of_a_Public_Person_and_Capital_Companies.pdf.

${ }_{91}$ Order of the Cabinet of Ministers No. 273 on Institution Coordinating the Governance of State-Owned Enterprises and Shares of 26 May 2015. 
- sporządzanie rocznych skonsolidowanych sprawozdań dotyczących przedsiębiorstw państwowych.

Centrum opracowało wytyczne ${ }^{92}$ oraz przyjęte następnie przez rząd rozporządzenia ${ }^{93}$ istotne $\mathrm{z}$ punktu widzenia wprowadzenia na Łotwie reform w zakresie zarządzania przedsiębiorstwami państwowymi, w szczególności dotyczące powoływania organów spółek, procesu nominacji, kryteriów nominacji, wynagrodzeń, podziału zysku oraz oceny działań przedsiębiorstw państwowych i ich strategii operacyjnych.

W czerwcu 2015 r., w wyniku nowelizacji ustawy PPCSCL, utworzono nową Radę instytucji koordynującej (art. 24 ustawy, rozporządzenie Rady Ministrów nr 518 z 2015 r. ${ }^{94}$ ) - organ o charakterze doradczym. Do zadań Rady należy m.in. opiniowanie projektów wytycznych dotyczących zarządzania udziałami państwa oraz projektów rozporządzeń opracowanych przez Międzyresortowe Centrum Koordynacji. Wydaje ona także zalecenia w razie konfliktu pomiędzy ministerstwem lub radą nadzorczą a Centrum dotyczącego strategii działania przedsiębiorstwa. W jej skład wchodzą, zgodnie z uchwałą rządu z września 2015 r., przedstawiciele ośmiu ministerstw (rolnictwa; kultury; gospodarki; ochrony

92 The Guidelines for Setting General Strategic Goals for ownership of the State in a Capital Company; The Guidelines for Drafting Medium-Term Operational Strategies of State-Owned Enterprises; The Guidelines for Publishing the Information for State-Owned Enterprises and Shareholders; The Guidelines for Assessment of Performance Results in Capital Companies where the State Exerts an Effective Control.

93 Cabinet Regulation No. 686 "Procedure for Nomination of Candidates for Posts of Management Board Members in Capital Companies where the State as a Participant (Shareholder) has the Right to Nominate Board and Supervisory Council Members and Board Members in SOEs with a Supervisory Council" of 1 December 2015; Cabinet Regulation No. 791 "Regulations on the Number of Management Board and Supervisory Council Members in Capital Companies of a Public Person and Public Private Capital Companies in Accordance with Indicators Characterising the Size of a Capital Company, Maximum Amount of Monthly Remuneration of Management Board and Supervisory Council Members"; Cabinet Regulation No. 806 "Procedure for State-Owned Enterprises and Public Private Capital Companies where the State is a Shareholder (Stockholder) to Anticipate and Determine the Share of Profit to be Paid in Dividends and Make Payments in the State Budget for the Use of Public Capital" of 22 December 2015; Cabinet Regulation No. 680 "Procedure for Making Deductions to the Privatisation Agency for the Privatisation of Public Property, Disposal of State-Owned Shares and other Activities Laid Down in Laws and Regulations, as well as for Establishing and Using a Reserve Fund and Making Payments to the State Budget"; Cabinet Regulation No. 95 "Procedure for Assessment of Performance Results and Financial Indicators for a Capital Company where the State Exerts an Effective Control" of 9 February 2016.

94 Cabinet Regulation No. 518 "Regulation on the Council of the Institution Coordinating Corporate Governance of State-Owned Enterprises and Shares" of 8 September 2015. 
środowiska i rozwoju regionalnego; finansów; zdrowia; sprawiedliwości; transportu) oraz Łotewskiego Stowarzyszenia Administracji Lokalnej i Regionalnej, Łotewskiej Konfederacji Unii Wolego Handlu i Konfederacji Pracodawców na Łotwie ${ }^{95}$.

\section{Niemcy}

Zadania państwa federalnego mogą być wykonywane przez jego właściwe organy lub przez przedsiębiorstwa (Unternehmen) publiczno-prawne lub prywatno-prawne. Przedsiębiorstwa publiczno-prawne są instytucjami z własną osobowością prawną, których cel, zadania i organizacja określone są w tzw. ustawach założycielskich (Errichtungsgesetz, Gründungsgesetz). Najbardziej znanym przykładem takiego przedsiębiorstwa jest niemiecki bank rozwoju, Kreditanstalt für Wiederaufbau ${ }^{96}$.

Zgodnie z $\$ 65$ ordynacji budżetowej ${ }^{97}$ państwo federalne może wypełniać swoje zadania poprzez udziały w przedsiębiorstwach zorganizowanych na podstawie prawa prywatnego jedynie pod warunkiem spełnienia określonych przesłanek. Przesłanki te, to: (a) istnienie ważnego interesu państwa, (b) niemożność osiągnięcia celu w sposób lepszy i bardziej ekonomiczny inną drogą, (c) ograniczenie obowiązku wnoszenia wpłat przez państwo, (d) utrzymanie przez państwo stosownego wpływu, w szczególności w radzie nadzorczej lub innym organie kontrolnym, oraz (e) zagwarantowanie, że roczne sprawozdanie finansowe i sprawozdanie $\mathrm{z}$ działalności są sporządzane i weryfikowane zgodnie z przepisami księgi III kodeksu handlowego dla dużych spółek kapitałowych ${ }^{98}$. Najważniejsze spółki z udziałem państwa to spółki akcyjne: Deutsche Post AG

95 Cross-Sectoral Coordination Centre: Annual Report 2016, s. 6, dostępny na stronie: http://www.valstskapitals.gov.lv/en/databases-and-annual-reports/annual-reports.

96 Raport Federalnego Ministerstwa Finansów o udziałach państwa: Die Beteiligungen des Bundes, Beteiligungsbericht 2017, Bundesministerium der Finanzen (dalej: BMF), Berlin, Februar 2018, s. 8, https://www.bundesfinanzministerium.de/Content/DE/ Standardartikel/Themen/Bundesvermoegen/Privatisierungs_und_Beteiligungspolitik/Beteiligungspolitik/Beteiligungsberichte/Beteiligungsbericht-des-bundes-2017. pdf?_blob=publicationFile\&v=7. Spośród takich publiczno-prawnych przedsiębiorstw, określanych zazwyczaj jako „zakłady” (Anstalten), w raporcie uwzględniono cztery: Kreditanstalt für Wiederaufbau, Bundesanstalt für Finanzmarktstabilisierung, FMS Wertmanagement AöR i Bundesanstalt für Immobilienaufgaben. Podlegają one nadzorowi Ministerstwa Finansów. Die Beteiligungen, op. cit., s. 13. Ze względu na „przejrzystośćc (sic!) zostały one umieszczone w części raportu dotyczącej bezpośrednich udziałów państwa w spółkach prawa prywatnego, ibidem, s. 8.

${ }_{97}$ Bundeshaushaltsordnung, $\mathrm{BHO}, \S 65$ ust. 1.

98 Die Beteiligungen, op. cit., s. 8. 


\section{Wykres 4. Bezpośrednie udziały państwa federalnego i jego majątku wydzielone- go (łącznie 106 przedsiębiorstw) w podziale na właściwe resorty}

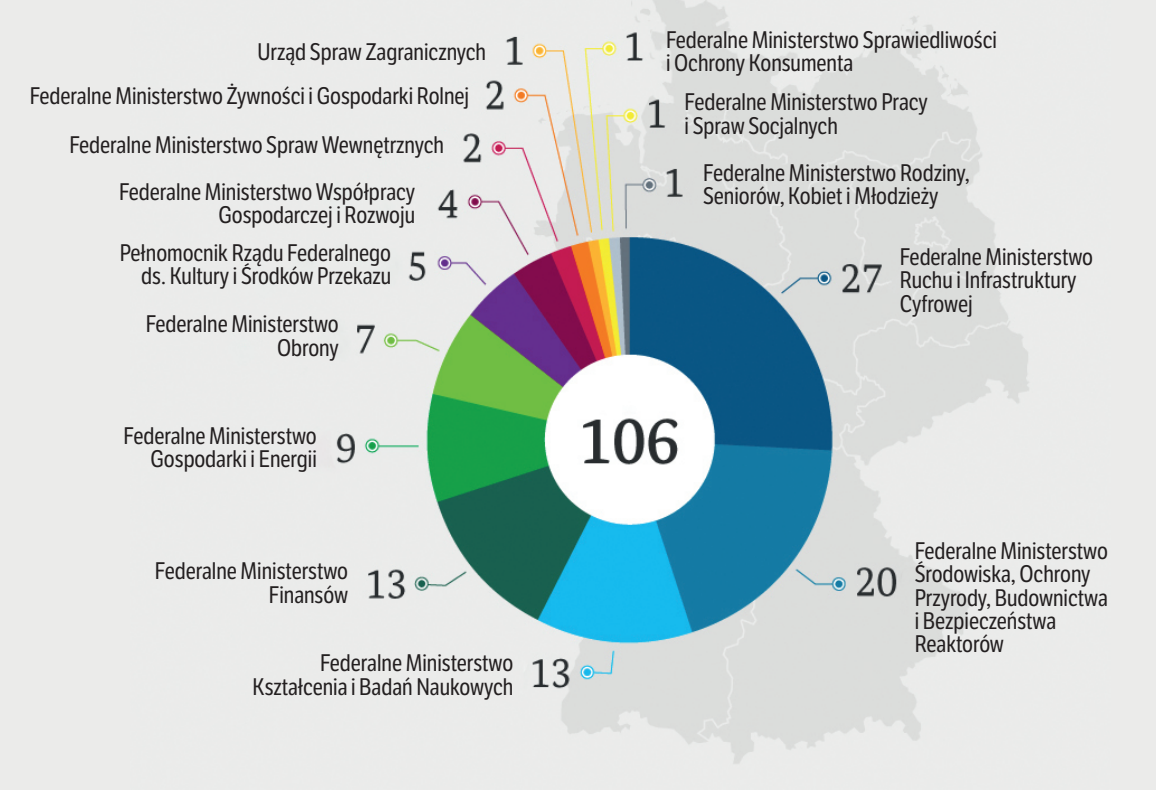

Źródło: Beteiligungspolitik, BMF, https://www.bundesfinanzministerium.de/Web/DE/Themen/Bundesvermoegen/Privatisierungs_und_Beteiligungspolitik/Beteiligungspolitik/beteiligungspolitik.html.

(20,50\% udziałów pośrednich), Deutsche Bahn AG (100\% udziałów bezpośrednich) i Deutsche Telekom AG (14,48\% udziałów bezpośrednich i 17,51\% udziałów pośrednich ${ }^{99}$.

Udziały państwa w przedsiębiorstwach są realizowane w sposób zdecentralizowany, czyli żadne ministerstwo nie zarządza wszystkimi przedsiębiorstwami państwowymi, lecz są one podzielone między różne resorty. Do zakresu działania Federalnego Ministerstwa Finansów (BMF) należy np. zarządzanie udziałem w Deutsche Telekom AG, do Ministerstwa Ruchu i Infrastruktury Cyfrowej w Deutsche Bahn AG ${ }^{100}$.

99 Te trzy spółki BMF wymienia jako najważniejsze w: Bedeutendste Beteiligungen des Bundes, BMF, https://www.bundesfinanzministerium.de/Web/DE/Themen/Bundesvermoegen/Privatisierungs_und_Beteiligungspolitik/Beteiligungspolitik/Bedeutendste-Bundesbeteiligungen/bedeutendste-bundesbeteiligungen.html. Udziały bezpośrednie i pośrednie państwa we wskazanych spółkach zob. Die Beteiligungen, op. cit., s. 13.

100 Beteiligungspolitik, BMF, https://www.bundesfinanzministerium.de/Web/DE/Themen/Bundesvermoegen/Privatisierungs_und_Beteiligungspolitik/Beteiligungspolitik/beteiligungspolitik.html. 
Federalne Ministerstwo Finansów udziela zezwolenia na założenie, nabycie i sprzedaż przedsiębiorstwa, rozwija federalny kodeks zarządzania spółkami publicznymi, wypracowuje wskazówki dotyczące dobrego prowadzenia przedsiębiorstwa oraz wytyczne w sprawach mianowań, szkoli członków rad nadzorczych i zarządzających udziałami, przeprowadza spotkania referentów ds. udziałów z przedstawicielami państwa federalnego i landów, zestawia roczne raporty z udziałów i przygotowuje regularnie raporty w sprawie zmniejszenia udziałów państwa $^{101}$.

Federalne Ministerstwo Finansów corocznie sporządza raport o udziałach państwa w przedsiębiorstwach. Zgodnie z ostatnim raportem z roku 2017 (stan na 31 grudnia 2016 r.) państwo miało bezpośrednie udziały w 106 przedsiębiorstwach, a pośrednie udziały przekraczające 25\% - w 469 przedsiębiorstwach spośród tych, których kapitał nominalny wynosił ponad 50 tys. euro.

Spośród wskazanych 106 przedsiębiorstw w 80 bezpośrednie udziały posiadało państwo, w tym w 58 spółkach prawa prywatnego prowadzących działalność gospodarczą, w 5 spółkach prawa prywatnego nieprowadzących działalności gospodarczej oraz w 17 spółdzielniach, których było członkiem.

Pozostałe 26 spośród 106 przedsiębiorstw to przypadki bezpośrednich udziałów majątku wydzielonego państwa w spółkach prawa prywatnego, w tym - w 24 spółkach prowadzących działalność gospodarczą i w 2 spółkach nieprowadzących działalności gospodarczej ${ }^{102}$.

Regulacje dotyczące zarządzania udziałami państwa federalnego w przedsiębiorstwach prawa prywatnego zawarte są w „Podstawach dobrego zarządzania przedsiębiorstwami i udziałami Federacji" ${ }^{103}$, w aktualnie obowiązującej formie wydane przez rząd federalny w dniu 1 lipca 2009 r. ${ }^{104}$. Jak wskazuje BMF, administrowanie udziałami państwa (Federacji) jest zdecentralizowane, to znaczy podzielone między właściwe ze względów przedmiotowych ministerstwa. „Podstawy" zapewnia jednolite realizowanie swoich obowiązków w tym zakresie przez poszczególne resorty. BMF jest głównym resortem odpowiedzialnym za stosowne regulacje. „Podstawy” składają się z trzech części. Częścią zasadniczą jest

101 Ibidem.

102 Die Beteiligungen, op. cit., s. 10.

103 Grundsätze guter Unternehmens- und Beteiligungsführung im Bereich des Bundes, BMF, 30. Juni 2009, https://www.bundesfinanzministerium.de/Content/DE/Standardartikel/Themen/Bundesvermoegen/Privatisierungs_und_Beteiligungspolitik/ Beteiligungspolitik/grundsaetze-guter-unternehmensfuehrung-anlage-de.pdf? blob=publicationFile\&v=5.

104 Beteiligungspolitik. Grundsätze guter Unternehmens- und Beteiligungsführung im Bereich des Bundes, BMF, https://www.bundesfinanzministerium.de/Web/DE/Themen/ Bundesvermoegen/Privatisierungs_und_Beteiligungspolitik/Beteiligungspolitik/ Grundsaetze-guter-Unternehmensfuehrung/grundsaetze-guter-unternehmensfuehrung.html. 
„Część A. Kodeks zarządzania korporacjami publicznymi Federacji” (Teil A. Public Corporate Governance Kodex des Bundes). Pozostałe dwie to „Część B. Wskazówki dotyczące dobrych praktyk w zarządzaniu udziałami w przedsiębiorstwach federalnych" (Teil B. Hinweise für gute Beteiligungsführung bei Bundesunternehmen) i „Część C. Wytyczne dotyczące mianowań” (Teil C. Berufungsrichtlinien) ${ }^{105}$.

Jak wskazuje BMF, ze względu na „zwiększenie przejrzystości” w „Kodeksie” (część A) ważną rolę odgrywają regulacje dotyczące jawności wynagrodzeń członków kierownictwa i rad nadzorczych. „Kodeks” stosuje się bezpośrednio do przedsiębiorstw, w których państwo ma udziały większościowe i które nie są notowane na giełdzie. Są to głównie spółki z ograniczoną odpowiedzialnością $(\mathrm{GmbH})$, na przykład Drukarnie Federalne (Bundesdruckerei BmbH), Niemiecka Kontrola Lotów (Deutsche Flugsicherung GmbH) czy też Niemieckie Towarzystwo Współpracy Międzynarodowej (Deutsche Gesellschaft für Internationale Zusammenarbeit $\mathrm{GmbH}$ ), ale także niektóre spółki akcyjne (AG), takie jak Koleje Niemieckie (Deutsche Bahn AG) czy też spółka doradcza w zakresie partnerstwa publiczno-prywatnego ÖPP Deutschland AG. W odniesieniu do przedsiębiorstw, w których państwo ma udziały mniejszościowe, regulacje „Kodeksu” są jedynie zalecane. Adresatami „Wskazówek” (część B) są komórki zarządzające udziałami państwa w przedsiębiorstwach. „Wskazówki” zapewniają „dobre”, zgodne z jednolitymi kryteriami zarządzanie, i zgodną z przepisami dbałość o interesy państwa i ułatwiają kontrolowanie udziałów, na podstawie postanowienia ordynacji budżetowej i ustaw budżetowych. „Wytyczne” (część C) dotyczą powoływania osób na stanowiska w radach nadzorczych i podobnych organach nadzorujących oraz w zarządach przedsiębiorstw, w których udziały ma państwo. Odnoszą się one również do innych instytucji, w których państwo ma wpływ na obsadę organów. W szczególności zawierają one przepisy dotyczące składu organów nadzorujących, w celu uniknięcia konfliktów interesów, oraz procedur obsadzania ${ }^{106}$.

Jak stwierdzają M. Bałtowski i G. Kwiatkowski w przywoływanej już książce: niemiecki sektor przedsiębiorstw państwowych nie jest szczegółowo opisany w literaturze naukowej, głównie z powodu względnie małego udziału własności państwowej $w$ gospodarce, a więc i małego znaczenia gospodarczego ${ }^{107}$. Wartość udziałów kapitałowych państwa niemieckiego w odniesieniu do PKB wynosiła według Eurostatu w 2016 r. 14,3\%, nieco poniżej średniej krajów UE (najwyższy wskaźnik w UE miała Finlandia 37,8\%, najniższy zaś Włochy - 8,1\%) ${ }^{108}$. Według danych OECD za rok 2012 wartość udziałów państwa w przedsiębiorstwach w odniesieniu do PKB wynosiła tylko 3,8\% i była bardzo niska w porównaniu ze

\footnotetext{
105 Ibidem.

106 Ibidem.

107 M. Bałtowski, G. Kwiatkowski, Przedsiębiorstwa państwowe, op. cit., s. 94.

108 Ibidem, s. 95, 266.
} 
znaczną większością badanych krajów (najwyższy wskaźnik: Finlandia - 44,8\%; najniższy: Hiszpania - 0,9\%; Polska - 22,1\% $)^{109}$.

Jak piszą cytowani autorzy, mimo: iż nadzór nad przedsiębiorstwami państwowymi $w$ Niemczech jest prowadzony w sposób transparentny i sformalizowany, to dotychczasowe próby stworzenia $w$ Niemczech spójnego prawa $w$ zakresie polityki właścicielskiej nie byly w pełni udane. Wskutek tego poszczególne zapisy sa rozrzucone po różnych aktach prawnych, zarówno na poziomie prawodawstwa federalnego, jak i poszczególnych landów $w^{110}$.

Model nadzoru nad udziałami państwowymi jest połączeniem modelu zdecentralizowanego i dualnego, w którym Ministerstwo Finansów określa ogólne wytyczne dla funkcjonowania sektora przedsiębiorstw państwowych, realizowane przez odpowiednie resorty branżowe oraz sprawuje ogólną kontrolę finansową nad całością sektora państwowego ${ }^{111}$.

$\mathrm{W}$ odniesieniu do kwestii obsadzania stanowisk w przedsiębiorstwach z udziałami państwa autorzy stwierdzają: $W$ procesie wyboru członków rad nadzorczych prawo do nominowania przynależy odpowiednim ministrom sektorowym. Zazwyczaj wymogi formalne wobec kandydatów do członków rad nadzorczych obejmuja wiedzę ekspercką i doświadczenie niezbędne do petnienia stanowiska, jednakże procedura wyboru nie jest ściśle sformalizowana. Kandydatura nie wymaga zgody żadnego komitetu nominacyjnego czy innego ciała doradczego, a jedynie aprobaty ministra. Model niemiecki nie cechuje się więc jasna procedura, która pozwalałaby na wybór profesjonalnych kandydatów i zmniejszenie wagi czynników czysto politycznych, niemniej ogólna kultura polityczna i dobre zwyczaje rządzenia sprawiają, że nietrafione, przypadkowe decyzje w tym zakresie zdarzaja się bardzo rzadko ${ }^{112}$.

\section{Wielka Brytania}

W Wielkiej Brytanii przedsiębiorstwa państwowe są tworzone i funkcjonują na podstawie kilku różnych form prawnych ${ }^{113}$ (należy zauważyć, że typy przedsiębiorstw w modelu anglosaskim różnią się od modelu kontynentalnego). Brytyjskie przedsiębiorstwa państwowe mogą mieć status spółki z odpowiedzialnością ograniczoną ze względu na wkład (private company limited by shares) lub spółki z odpowiedzialnością ograniczoną ze względu na gwarancję/zobowiązanie (private company limited by guarantee). Są to rodzaje private limited company (LTD),

109 Ibidem, s. 95, 255.

110 Ibidem, s. 97.

111 Ibidem, s. 98.

112 Ibidem.

113 National Audit Office, Companies in government, „Briefing” 2015, s. 10, https://www. nao.org.uk/report/companies-in-government/. 
które stanowią odpowiednik polskiej spółki z ograniczoną odpowiedzialnością. Te podmioty działają na podstawie ustawy o przedsiębiorstwach z 2006 r. (Companies Act 2006) ${ }^{114}$ i podlegają ewidencji prowadzonej przez Companies House. W przypadku przedsiębiorstw o statusie private company limited by shares udziałowcy odpowiadają za zobowiązania przedsiębiorstwa do wysokości wniesionego wkładu. Natomiast przedsiębiorstwa o statusie private company limited by guarantee nie mają udziałowców, lecz członków, którzy odpowiadają za zobowiązania przedsiębiorstwa zgodnie z postanowieniami statutu spółki (zwykle jest to kwota w symbolicznej wysokości, np. 1 funt) ${ }^{115}$. Trzecia dopuszczalna forma prawna to karta królewska/statut królewski (Royal Charter), rozwiązanie specyficzne dla anglosaskiego porządku prawnego. Instytucje działające na podstawie tego aktu prawnego to instytucje publiczne (uczelnie, towarzystwa naukowe itp., zaś wśród przedsiębiorstw państwowych można wskazać np. BBC). Czwarta forma prawna brytyjskich przedsiębiorstw państwowych to przedsiębiorstwa utworzone i funkcjonujące na podstawie odrębnej ustawy (statutory company). Państwowe podmioty powołane na podstawie odrębnej ustawy to przede wszystkim instytucje zajmujące się dostarczaniem usług publicznych. Kolejną, odrębną kategorię stanowią jednostki publiczne wydzielone $\mathrm{z}$ administracji rządowej (non-departmental public body). W przeciwieństwie do czterech poprzednich kategorii, których podstawą prawną są powszechnie obowiązujące akty normatywne, jednostki publiczne (public bodies) są powoływane decyzją ministerstwa i funkcjonują na podstawie statutu przyjętego przez ministerstwo. Celem wyodrębnienia tych podmiotów ze struktur rządowych jest zagwarantowanie im większej niezależności. W określonych przypadkach jednostki publiczne mogą uzyskać status prawny spółki zgodnie z przywołaną wcześniej ustawą o przedsiębiorstwach z 2006 r.

Zróżnicowanie form prawnych, na podstawie których funkcjonują brytyjskie przedsiębiorstwa państwowe, a także brak jednej, centralnej instytucji, która odpowiada za zarządzanie czy choćby ewidencję przedsiębiorstw państwowych, oraz brak jednej, powszechnie uznanej definicji przedsiębiorstwa państwowego sprawiają, że w rozmaitych dokumentach państwowych podaje się wyraźnie odbiegające od siebie dane na temat liczby brytyjskich przedsiębiorstw państwowych. Na przykład w sprawozdaniu przygotowanym przez biuro analityczne Izby Gmin podaje się, że 303 przedsiębiorstwa stanowią „wyłączną, większościową lub wspólną własność publiczną"116. Z kolei w sprawo-

114 Https://www.legislation.gov.uk/ukpga/2006/46/contents.

115 Limited by Shares or Guarantee?, https://www.communitycompanies.co.uk/companies-limited-by-guarantee.

116 House of Commons Library, Public ownership of industries and services, „Briefing paper” 2018, s. 14, https://researchbriefings.parliament.uk/ResearchBriefing/Summary/ CBP-8325. 
zdaniu przygotowanym przez National Audit Office (odpowiednik Najwyższej Izby Kontroli) stwierdza się, że: aktualnie nie ma jednego źródła danych, które jednoznacznie określa liczbę przedsiębiorstw państwowych ${ }^{117}$. Funkcjonują trzy bazy danych, z których można pozyskać informacje na ten temat (Public Bodies Data Directory - dane rządowe; Public Sector Classification Index - dane Office for National Statistics, czyli urzędu statystycznego; Whole of Government Accounts - dane HM Treasury, czyli ministerstwa finansów), jednak posługują się one odmiennymi definicjami oraz różną metodologią opracowywania danych. W przytoczonym sprawozdaniu National Audit Office wskazano, że $\mathrm{w}$ tych bazach mianem państwowych łącznie określa się 84 przedsiębiorstwa, z czego 27 przedsiębiorstw występuje we wszystkich trzech bazach. Natomiast zgodnie z metodologią przyjętą przez samo National Audit Office liczbę brytyjskich przedsiębiorstw państwowych określono na 218 (by zidentyfikować te przedsiębiorstwa, posłużono się wspomnianymi bazami danych, informacjami z rocznych sprawozdań poszczególnych ministerstw oraz informacjami z ewidencji spółek prowadzonej przez Companies House) ${ }^{118}$. Ponadto warto dodać, że na udziale przedsiębiorstw państwowych w rynku i ich znaczeniu dla krajowej gospodarki piętno odcisnęła polityka zapoczątkowana przez Margaret Thatcher. Podczas rządów Partii Konserwatywnej (1979-1997) udział wartości dodanej brutto (GVA, gross value added) wypracowanej przez przedsiębiorstwa państwowe spadł z 10,9\% do $2,2 \%{ }^{119}$.

Jeśli chodzi o sprawowanie nadzoru właścicielskiego, to w brytyjskim modelu nie ma bezpośredniego związku między formą prawną, na podstawie której funkcjonuje dane przedsiębiorstwo państwowe, a sposobem sprawowania nadzoru właścicielskiego. Niezależnie od przyjętej formy prawnej, przedsiębiorstwa państwowe znajdują się w jednej z trzech możliwych relacji z organem sprawującym nadzór właścicielski ${ }^{120}$. Pierwsza możliwość to bezpośredni stosunek. W tym wypadku ministerstwo jest właścicielem przedsiębiorstwa państwowego będącego jednostką zależną (subsidiary), np. Ministerstwo Zdrowia jest właścicielem NHS Property Services Limited, jednostki zarządzającej mieniem wykorzystywanym przez instytucje systemu opieki zdrowotnej. Druga możliwość to stosunek pośredni, w którym w imieniu rządu zadania związane ze sprawowaniem nadzoru właścicielskiego nad określonymi przedsiębiorstwami państwowymi pełni odrębny, powołany specjalnie w tym celu organ. Obecnie te zadania pełni UK Government Investments Limited (Brytyjskie Inwestycje Rządowe). Organ ten został utworzony w 2016 r. w wyniku połączenia dwóch wcześniej działających

117 National Audit Office, Companies in government, op. cit., s. 5.

118 Ibidem, s. 6-7.

119 State-Owned Enterprises in the EU: Lessons Learnt and Ways Forward in a Post-Crisis Context, s. 95, https://ec.europa.eu/info/sites/info/files/file_import/ip031_en_2.pdf.

120 National Audit Office, Companies in government, op. cit., s. 9 i s. 29. 
organów. UK Government Investments Limited pełni zadania, które przejął po swoich poprzednikach: po UK Financial Investment przejął zarządzanie udziałami posiadanymi przez rząd brytyjski w bankach Lloyds i Royal Bank of Scotland, natomiast po Shareholder Executive przejął sprawowanie nadzoru właścicielskiego nad określonymi przedsiębiorstwami stanowiącymi wyłączną lub częściową własność państwa. Należą do nich m.in. Urenco (ośrodek wzbogacania uranu), Channel 4 (stacja telewizyjna), National Nuclear Laboratories (ośrodek wsparcia eksperckiego i technologicznego dla branży energetyki jądrowej), Land Registry (rejestr gruntów), Ordnance Survey (instytut kartograficzny), Nuclear Liabilities Fund (fundusz na rzecz wycofywania z eksploatacji obiektów jądrowych), Export Finance (instytucja udzielająca pożyczek eksporterom), Royal Mint (mennica). UK Government Investments sprawuje nadzór właścicielski nad 27 przedsiębiorstwami państwowymi ${ }^{121}$. Natomiast trzecia możliwość to współdzielenie odpowiedzialności. W takim wypadku własność danego przedsiębiorstwa państwowego i zarządzanie nim jest sprawowane łącznie przez dwa lub więcej ministerstw, np. nadzór właścicielski nad Student Loans Company Limited (podmiot udzielający pożyczek studenckich) sprawują: brytyjskie Ministerstwo Przedsiębiorczości, Energetyki i Strategii Przemysłowej, północnoirlandzkie Ministerstwo Pracy i Szkoleń, walijskie Ministerstwo Edukacji i Szkoleń oraz rząd szkocki (zarówno organ centralny, jak i organy pochodzące z poszczególnych części składowych państwa).

Należy zatem podkreślić różnorodność dopuszczalnych form prawnych i zróżnicowanie typów relacji przedsiębiorstw państwowych z organami sprawującymi nadzór. Środki wykorzystywane do sprawowania nadzoru nad przedsiębiorstwem państwowym zależą od przyjętej w danym wypadku formy prawnej, a należą do nich: prawo do nominowania, zatwierdzania i dymisjonowania członków zarządu, podejmowanie decyzji w sprawie przyznania środków finansowych oraz wskazywanie celów i zadań, na które te środki należy przeznaczyć, podejmowanie decyzji w sprawie celów, zadań, kompetencji, struktury organizacyjnej danego przedsiębiorstwa państwowego ${ }^{122}$. Niezależnie od formy prawnej, przedsiębiorstwa państwowe (i inne instytucje publiczne) zobowiązane są przestrzegać postanowień zawartych w „Managing Public Money”123, wydanym przez Ministerstwo Finansów dokumencie zawierającym wytyczne w sprawie gospodarnego, celowego, przejrzystego zarządzania środkami publicznymi.

${ }^{121}$ UK Government Investments. What we do, https://www.ukgi.org.uk/what-we-do/our-partner-bodies/.

122 National Audit Office, Companies in government, op. cit., s. 11.

123 HM Treasury, Managing public money, https://assets.publishing.service.gov.uk/government/uploads/system/uploads/attachment_data/file/742188/Managing_Public_Money__MPM_2018.pdf. 


\section{Włochy}

Przedsiębiorstwa państwowe są obecne we włoskiej gospodarce od drugiej połowy XIX wieku. Ich rola zaczęła się istotnie zwiększać w okresie rządów B. Mussoliniego. W $1931 \mathrm{r}$. utworzony został pierwszy holding państwowy - IRI (Instituto per la Riconstruzione Industriale), którego głównym zadaniem było przejmowanie udziałów w prywatnych przedsiębiorstwach zagrożonych bankructwem ${ }^{124}$. Zapoczątkowało to falę nacjonalizacyjną okresu faszyzmu. Holding IRI, początkowo założony jako podmiot tymczasowy, w krótkim czasie stał się wielkim przedsiębiorstwem kontrolującym większość włoskiej gospodarki, a przede wszystkim strategiczne sektory: stoczniowy, stalowy i telekomunikacyjny ${ }^{125}$. W konsekwencji w latach 30. XX wieku udział własności państwowej w gospodarce wynosił prawie 15\% (w tym czasie tylko w ZSRR te wartości były wyższe $^{126}$ ). W okresie powojennym rynek został zdominowany przez nowo utworzone państwowe megakoncerny w sektorach energetyczno-gazowym, ubezpieczeń i przemyśle, nad którymi kontrolę sprawowało powołane w tym celu Ministerstwo Udziałów Skarbu Państwa. Zmiana takiego systemu gospodarczego rozpoczęła się w latach 70 . XX wieku ze względu na kryzys finansowy, niską wydajność przedsiębiorstw państwowych oraz postęp technologiczny. W wyniku procesów prywatyzacyjnych prawie wszystkie wielkie koncerny (w tym IRI, obecnie nieistniejący) zostały przekształcone w spółki prawa handlowego (spółki akcyjne). W 1993 r. zlikwidowane zostało Ministerstwo Udziałów Skarbu Państwa a model nadzoru właścicielskiego zaczął ewoluować od holdingowego do dualnego. Włoska gospodarka z przełomu XX i XXI wieku charakteryzuje się stosunkowo wysokim udziałem własności publicznej w sektorze przedsiębiorstw. Mimo to, informacje na temat liczby i rodzajów takich przedsiębiorstw są ograniczone i niespójne. Zgodnie z danymi z 2012 r. przedstawionymi przez OECD państwo włoskie miało udziały większościowe w 7 spółkach notowanych na giełdzie, zatrudniających łącznie prawie 277 tys. osób oraz było właścicielem 10 nienotowanych na giełdzie przedsiębiorstw, zatrudniających 250 tys. osób. Dane te różnią się od informacji wynikających z przygotowanego przez OECD raportu z $2017 \mathrm{r}$. Zgodnie $\mathrm{z}$ tym raportem państwo posiada udziały większościowe $\mathrm{w} 11$ spółkach giełdowych, z czego 2 prowadzą działalność w sektorze surowcowym, 4 w sektorze energetyczno-gazowym, a $3 \mathrm{w}$ przemyśle, które zatrudniają łącznie ponad 400 tys. osób ${ }^{127}$. Ponadto państwo jest właścicielem 9 przedsiębiorstw nienoto-

124 M. Bałtowski, G. Kwiatkowski, Przedsiębiorstwa państwowe, op. cit., s. 109.

125 Ibidem.

126 Ibidem.

127 OECD, The Size and Sectoral Distribution of State-Owned Enterprises, https://read. oecd-ilibrary.org/governance/the-size-and-sectoral-distribution-of-state-owned-enterprises_9789264280663-en\#page58. 
wanych na giełdzie (w sektorach przemysłu, usług finansowych oraz transportu), zatrudniających prawie 100 tys. osób. Zgodnie z danymi przedstawionymi w opracowaniu Międzynarodowego Centrum Badań i Informacji Ekonomicznej (International Centre of Research and Information on the Public, Social and Cooperative Economy, CIRIEC) z 2015 r. przedsiębiorstwa państwowe stanowiły 5\% sektora przedsiębiorstw we Włoszech. Oznacza to, że działalność prowadziło 70 takich podmiotów, zatrudniających łącznie ponad 582 tys. osób. Jako główne sektory działalności wskazano na sektor gazowo-energetyczny (23), sektor usług publicznych, takich jak wodociągi, lotniska, poczta (24) i sektor transportu (5). Zgodnie z informacjami przedstawionymi przez Komisję Europejską w opracowaniu z 2016 r. ogólna liczba przedsiębiorstw publicznych we Włoszech wyniosła 7,7 tys., z czego ponad 6 tys. stanowiły państwowe przedsiębiorstwa lokalne. Włoska Izba Handlowa zaś określiła liczbę lokalnych przedsiębiorstw państwowych na 8,8 tys. Rozbieżności te mogą wynikać z braku jednolitej definicji przedsiębiorstwa państwowego i różnych kryteriów przyjmowanych przez przygotowujące raporty podmioty. Wskaźniki znaczenia sektora przedsiębiorstw państwowych OECD dla Włoch, w porównaniu z innymi państwami wysoko rozwiniętymi znajdują się na średnim poziomie, z tendencją malejącą ${ }^{128}$. Wskaźnik PMR-PO w 2013 r. wyniósł dla Włoch 2,54, co daje wynik poniżej średniej wyliczonej dla państw wysoko rozwiniętych $(2,62)$. W przypadku drugiego wskaźnika - CSS - mierzącego udział przedsiębiorstw państwowych w grupie największych przedsiębiorstw danego kraju jego wartość dla Włoch w roku 2011 wyniosła 0. Taki wynik oznacza brak własności państwowej wśród największych przedsiębiorstw. Również w przypadku wskaźnika IPE, określającego sumę wartości przychodów różnego typu przedsiębiorstw państwowych w odniesieniu do PKB Włochy uzyskały stosunkowo niski wynik. W 2007 r. wartość tego wskaźnika wyniosła 2,17, co dawało wynik znacznie poniżej średniej dla państw wysoko rozwiniętych $(3,04)^{129}$. Warto zwrócić uwagę na fakt, że omówione wskaźniki, ze względu na trudności w pozyskaniu spójnych danych mogą nie dawać pełnego obrazu wielkości i znaczenia sektora przedsiębiorstw państwowych we Włoszech.

System nadzoru właścicielskiego we Włoszech przeszedł ewolucję od modelu holdingowego do obowiązującego obecnie modelu dualnego. Charakteryzuje się on podziałem obowiązków właścicielskich między organy centralne (np. premiera, Ministerstwo Finansów lub inne ministerstwo) a inne organy o charakterze sektorowym. W modelu włoskim nadzór jest sprawowany przez Departament Skarbu w Ministerstwie Gospodarki i Finansów w zakresie ogólnej polityki właścicielskiej i kontroli finansowej oraz przez ministerstwa resortowe.

Działalność gospodarcza może być prowadzona przez państwo w różnych formach, w sposób bezpośredni oraz pośredni. Bezpośrednią formą prowadzenia

128 M. Bałtowski, G. Kwiatkowski, Przedsiębiorstwa państwowe, op. cit., s. 112.

129 Ibidem, s. 252. 
działalności przez państwo są agencje rządowe (gestioni dirette ministeriali oraz aziende autonome statali), które nie mają osobowości prawnej i zajmują się działaniami niekomercyjnymi ${ }^{130}$. Wśród form pośrednich formą organizacyjno-prawną pozwalającą na pełną kontrolę administracyjną jest publiczny byt ekonomicz$\mathrm{ny}^{131}$ - EPE (ente pubblico economico). Zgodnie $\mathrm{z}$ art. 2201 Kodeksu cywilnego (Codice civile) jedynym celem funkcjonowania takich podmiotów może być prowadzenie komercyjnej działalności gospodarczej. Podlegają one obowiązkowi rejestracji w odpowiednim rejestrze. Mimo iż prawnie ich funkcjonowanie regulują przepisy prawa handlowego, na zasadach podobnych do przedsiębiorstw prywatnych, są to podmioty publiczne, należące do państwa. Szczególną kategorię EPE stanowią ente di gestione - holdingi, które zarządzają akcjami lub udziałami w innych podmiotach. Na skutek zmian sytemu gospodarczego EPE zaczęły być stopniowo przekształcane na mocy dekretów prawnych w spółki akcyjne (transformacja taka objęła większość tworzonych po wojnie megakoncernów państwowych, w tym IRI). Na dominację podmiotów prawa prywatnego miał wpływ rozwój technologiczny, integracja europejska i postępująca liberalizacja rynku. Ponadto uwidocznione zostały problemy związane z zarządzaniem EPE przez państwo: nadzatrudnienie, bardzo silna pozycja społeczno-ekonomiczna oraz brak przejrzystości finansowej w relacjach między państwem i $\mathrm{EPE}^{132}$. Jednym z nielicznych przedsiębiorstw państwowych działających nadal w formie EPE jest Agenzia del demanio, odpowiadająca za zarządzanie nieruchomościami państwowymi.

Państwo włoskie może wykonywać uprawnienia właścicielskie także przez posiadanie udziałów w spółkach prawa prywatnego. Formą prawną spółek z dominującym kapitałem państwowym jest societa per azioni pubbliche, natomiast spółki, w których Skarb Państwa ma udziały mniejszościowe, nazywane są societa a partecipazione mista. Ponadto do tworzenia lokalnych przedsiębiorstw publicznych (spółek mieszanych z udziałem kapitału prywatnego) uprawnione są także jednostki samorządu terytorialnego (na podstawie ustawy nr 142 z 8 czerwca 1990 r.). Formą prawną takich spółek jest aziende speciali (municippalizzate).

W 2001 r. powołana została oddzielna, jednoosobowa spółka włoskiego Skarbu Państwa - SICOT (Sistemi di Consulenza per il Tesoro), wyspecjalizowana $\mathrm{w}$ doradztwie związanym $\mathrm{z}$ wykonywaniem uprawnień właścicielskich przez ograny władzy publicznej. Do głównych zadań spółki należało doradzanie Departamentowi Skarbu Ministerstwa Gospodarki i Finansów w zakresie funkcji właścicielskich państwa, monitorowanie działalności spółek z udziałem Skarbu Państwa, merytoryczne wspieranie rządu przy procesach prywatyzacyjnych, wspieranie programów inwestycyjnych z udziałem kapitału publicznego ${ }^{133}$.

$130 \quad$ Ibidem, s. 113.

131 F. Grzegorczyk, Przedsiębiorstwo publiczne, op. cit., s. 147.

132 Ibidem, s. 149.

133 M. Bałtowski, G. Kwiatkowski, Przedsiębiorstwa państwowe, op. cit., s. 114. 
W 2014 r. SICOT połączona została z inną jednoosobową spółką Skarbu Państwa - CONSIP, powiększając zakres swojej działalności o doradztwo w zakresie szeroko rozumianych zasobów publicznych.

Organ centralny sprawujący nadzór nad przedsiębiorstwami państwowymi Departament Skarbu Ministerstwa Gospodarki i Finansów - wykonuje wobec spółek, w których jest udziałowcem, uprawnienia właścicielskie, zgodnie z przepisami prawa handlowego. Ministerstwo ma również „złote uprawnienia”, jednakże tylko w razie wyjątkowych operacji w sektorze obronności i bezpieczeństwa narodowego, energetycznym, transportowym i telekomunikacyjnym. Warto zauważyć, że akcjonariusze mniejszościowi w takich spółkach mają nieproporcjonalnie większe prawo głosu w stosunku do posiadanych udziałów w procesie wyboru rady nadzorczej ${ }^{134}$.

Jedną z zasad nadzoru właścicielskiego we Włoszech jest transparentność, wprowadzana przez włoskiego ustawodawcę zgodnie z zaleceniami OECD. W 2013 r. Ministerstwo Gospodarki i Finansów wydało rozporządzenie, zgodnie z którym wszystkie przedsiębiorstwa państwowe nienotowane na giełdzie muszą przedstawić sprawozdanie dotyczące zasad zarządzania, analizy wydajności zarządzania przedsiębiorstwem, osiągniętych wyników finansowych oraz prognoz na przyszłość ${ }^{135}$. Ponadto $\mathrm{w}$ ostatnich latach przyjęty został pakiet przepisów (m.in. ustawa nr 97/2016 zmieniającą ustawę nr 33/3013) ${ }^{136}$ mających na celu poprawę transparentności i wydajności przedsiębiorstw oraz walkę z korupcją. Przedsiębiorstwa publiczne zobowiązane są m.in. do: przeprowadzania kontroli wewnętrznych oraz audytów zewnętrznych nadzorowanych przez Sąd Audytorów; przygotowywania skonsolidowanych sprawozdań finansowych; stosowania się do strategii antykorupcyjnej i zaleceń „Narodowego planu antykorupcyjnego” (Piano Nazionale Anticorruzione) ${ }^{137}$. Zgodnie z włoskimi przepisami o zakresie i sposobie implementacji zasady transparentności w przedsiębiorstwach państwowych decyduje kryterium kontroli publicznej nad przedsiębiorstwem oraz kryterium działań na rzecz interesu publicznego.

We Włoszech funkcjonuje duża liczba lokalnych przedsiębiorstw publicznych, nad którymi nadzór sprawują władze samorządu terytorialnego różnych szczebli. Mogą to być przedsiębiorstwa działające na poziomie gmin, prowincji lub regionów. Przedsiębiorstwa lokalne działają we wszystkich sektorach gospodarki. Zgodnie z analizami przygotowanymi przez Komisję Europejską lokalne przedsiębiorstwa publiczne we Włoszech działają w szczególnej i skompliko-

134 Ibidem.

135 Http://www.ciriec.ulg.ac.be/wp-content/uploads/2016/02/WP15-19-1.pdf.

136 M. Bertocchi, Transparency in Local State-Owned Enterprises in Italy, "Emerging Issues in Management" 2017, nr 2.

137 Rezolucją 1074 z 21 listopada 2018 r. został przyjęty uaktualniony nowy „Narodowy plan antykorupcyjny”, http://www.anticorruzione.it/portal/rest/jcr/repository/collaboration/Digital\%20Assets/anacdocs/Attivita/Atti/Delibere/2018/PNA_2018.pdf. 
wanej konfiguracji prawnej ${ }^{138}$. Około $1 / 3$ takich przedsiębiorstw zatrudnia mniej niż 6 pracowników, a prawie połowa zatrudnia większą liczbę dyrektorów niż pracowników. Co więcej, prawie $1 / 3$ lokalnych przedsiębiorstw publicznych przynosi straty. Wśród największych problemów tego sektora Komisja Europejska wymienia prowadzenie działalności z pogwałceniem przepisów prawa włoskiego i europejskiego (brak konkurencji, duże upolitycznienie i przyznawanie kontraktów publicznych bez wcześniejszego ogłaszania przetargu przez władze lokalne).

Zdecydowana większość lokalnych przedsiębiorstw publicznych funkcjonuje jako spółki prawa prywatnego, w związku z czym podlega ogólnym przepisom prawa handlowego oraz prawa podatkowego. W celu zmniejszenia wydatków publicznych i zniechęcenia jednostek samorządu terytorialnego do powoływania lokalnych przedsiębiorstw, które nie generowałyby zysków, włoski ustawodawca wprowadził liczne wyjątki i przepisy szczególne dla przedsiębiorstw państwowych nienotowanych na giełdzie. Należą do nich m.in. górna granica wynagrodzeń dla członków zarządu takich spółek, surowsze procedury rekrutacyjne, obowiązek kontroli przez Sąd Audytorów, limity wydatków na usługi konsultingowe i inne ${ }^{139}$. Mimo działań podejmowanych na poziomie legislacyjnym przedsiębiorstwa państwowe nadal pozostają pod wypływami politycznymi, co jest szczególnie widoczne w przypadku obsady rad nadzorczych w spółkach z udziałem Skarbu Państwa ${ }^{140}$.

\section{Bibliografia}

Bałtowski M., Kwiatkowski G., Przedsiębiorstwa państwowe we współczesnej gospodarce, Warszawa 2018.

Bertocchi M., Transparency in Local State-Owned Enterprises in Italy, "Emerging Issues in Management" 2017, nr 2.

Bouda P., Fadrný M., Správa a řízení státem vlastněných podniků ve Velké Británii a v České republice. Inspirace pro změnu, Brno 2015.

Grzegorczyk F., Przedsiębiorstwo publiczne kontrolowane przez państwo - zagadnienia konstrukcyjne, Warszawa 2012.

Hroch J., Státní podniky v České republice a v Evropě, https://www.kulturni-noviny.cz/nezavisle-vydavatelske-a-medialni-druzstvo/archiv/online/2015/46-2015/5648fbb1f147d.

Somai M., Ewolucja interwencji państwa w gospodarkę - na przykładzie Francji i Słowenii, „Studia Ekonomiczne” 2016, nr 4.

138 European Commission, Local State-Owned Enterprises in Italy: Inefficiencies and Ways Forward, https://ec.europa.eu/info/sites/info/files/file_import/eb010_en_2.pdf.

139 Ibidem.

140 M. Bałtowski, G. Kwiatkowski, Przedsiębiorstwa państwowe, op. cit., s. 116. 